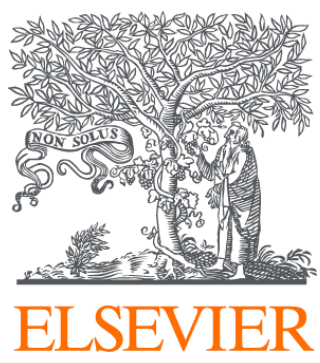

Since January 2020 Elsevier has created a COVID-19 resource centre with free information in English and Mandarin on the novel coronavirus COVID-

19. The COVID-19 resource centre is hosted on Elsevier Connect, the company's public news and information website.

Elsevier hereby grants permission to make all its COVID-19-related research that is available on the COVID-19 resource centre - including this research content - immediately available in PubMed Central and other publicly funded repositories, such as the WHO COVID database with rights for unrestricted research re-use and analyses in any form or by any means with acknowledgement of the original source. These permissions are granted for free by Elsevier for as long as the COVID-19 resource centre remains active. 


\title{
The Mpro structure-based modifications of ebselen derivatives for improved antiviral activity against SARS-CoV-2 virus
}

\author{
Zhen Qiao $^{\text {a, }}$, Ningning Wei ${ }^{\text {a,c, },}$, Lin Jin ${ }^{\text {b, }}{ }^{\text {, Hongyi Zhang }}{ }^{\text {a }}$, Jiajie Luo ${ }^{\text {a }}$, Yanru Zhang ${ }^{\text {a,c, }}$, \\ KeWei Wang ${ }^{\text {a,c, d,* }}$ \\ ${ }^{a}$ Departments of Pharmacology and Medicinal Chemistry, School of Pharmacy, Qingdao University Medical College, \#1 Ningde Road, Qingdao 266073, China \\ ${ }^{\mathrm{b}}$ Key Laboratory of Animal Models and Human Disease Mechanisms of Chinese Academy of Sciences/Key Laboratory of Bioactive Peptides of Yunnan Province, Kunming \\ Institute of Zoology, Chinese Academy of Sciences, Kunming, Yunnan 650223, China \\ ${ }^{\mathrm{c}}$ Institute of Innovative Drug Discovery, Qingdao University, 38 Dengzhou Road, Qingdao 266021, China \\ d Guangdong-Hong Kong-Macao Greater Bay Area Center for Brain Science and Brain-Inspired Intelligence, Guangzhou, China
}

\section{A R T I C L E I N F O}

\section{Keywords:}

The main protease

SARS-CoV-2 virus

Ebselen derivatives

Antiviral

Noncovalent inhibitor

\begin{abstract}
A B S T R A C T
The main protease (Mpro or 3CLpro) of SARS-CoV-2 virus is a cysteine enzyme critical for viral replication and transcription, thus indicating a potential target for antiviral therapy. A recent repurposing effort has identified ebselen, a multifunctional drug candidate as an inhibitor of Mpro. Our docking of ebselen to the binding pocket of Mpro crystal structure suggests a noncovalent interaction for improvement of potency, antiviral activity and selectivity. To test this hypothesis, we designed and synthesized ebselen derivatives aimed at enhancing their non-covalent bonds within Mpro. The inhibition of Mpro by ebselen derivatives $(0.3 \mu \mathrm{M})$ was screened in both HPLC and FRET assays. Nine ebselen derivatives (EBs) exhibited stronger inhibitory effect on Mpro with IC 50 of $0.07-0.38 \mu \mathrm{M}$. Further evaluation of three derivatives showed that EB2-7 exhibited the most potent inhibition of SARS-CoV-2 viral replication with an $\mathrm{IC}_{50}$ value of $4.08 \mu \mathrm{M}$ in HPAepiC cells, as compared to the prototype ebselen at $24.61 \mu \mathrm{M}$. Mechanistically, EB2-7 functions as a noncovalent Mpro inhibitor in LC-MS/MS assay. Taken together, our identification of ebselen derivatives with improved antiviral activity may lead to developmental potential for treatment of COVID-19 and SARS-CoV-2 infection.
\end{abstract}

\section{Introduction}

The severe acute respiratory syndrome coronavirus 2 (SARS-CoV-2) causes the pandemic coronavirus disease 2019 (COVID-19) that is still in unexpected spread without therapy $[1,2]$. The SARS-CoV-2 gene encodes a viral 3-chymotrypsin-like protease (3CLpro, also known as Mpro) that controls coronavirus replication $[3,4]$. Mpro is a cysteine protease containing a catalytic center responsible for specific enzymatic cleavage and serves as a target for antiviral drugs [4-6]. Based on the catalytic activity of Mpro, a widely used fluorescence resonance energy transfer (FRET) assay has been adapted for screen of various peptidomimetics and small molecules that show as Mpro inhibitors within a micro- to nanomolar range [7-13].

A large-scale compound repurposing effects have recently identified a multifunctional organoselenium drug candidate ebselen as a promising Mpro inhibitor that is currently in clinical phase III trial for meniere's disease and phase II trial for bipolar disorder [14-16]. Ebselen inhibits the Mpro with an $\mathrm{IC}_{50}$ of $0.67 \mu \mathrm{M}$ and exhibits antiviral activity with $\mathrm{IC}_{50}$ at $4.67 \mu \mathrm{M}$. Ebselen (PZ51, DR-3305), a glutathione peroxidase mimic, has also been reported to function as antioxidant and antiinflammatory agent with therapeutic potential in neurological disorders, noise-induced hearing loss, cancers acute pancreatitis, mania and hypomania [17-26]. Ebselen also inhibits other viral cysteine proteases including SARS-CoV-2 papain-like protease and 2Apro or 3Cpro from enterovirus A71 (EV-A71) and EV-D68, indicating that ebselen is a multi-target drug candidate [27].

Recent crystal structures of ebselen-Mpro complex show that ebselen forms covalent bond with Cys145 (PDB: 7BAK) [28] and Cys44 (PDB: 7BFB) of Mpro. Mass spectrometry analysis also reveals ebselen is a covalent inhibitor of Mpro [14,27,29-31]. Based on these observations,

\footnotetext{
* Corresponding authors at: Departments of Pharmacology and Medicinal Chemistry, School of Pharmacy, Qingdao University Medical College, \#1 Ningde Road, Qingdao 266073, China.

E-mail addresses: yanru.zhang@qdu.edu.cn (Y. Zhang),wangkw@qdu.edu.cn (K. Wang).

1 These authors contributed equally.
} 
we designed and synthesized a series of ebselen derivatives by increasing the non-covalent interaction with Mpro for enhancing the inhibitory efficacy. Among these compounds, three ebselen derivatives exhibit potent inhibition of SARS-CoV-2 replication with improved antiviral activity and selectivity.

\section{Results and discussion}

\subsection{Mpro structure-based design of ebselen derivatives}

Based on the Mpro structure information (PDB: 7BAK and 7BFB), we started performing the molecular docking of ebselen into Mpro. As shown in Fig. 1A, ebselen fits to the binding pocket of ebselen-Mpro complex with a similar pose and its carbonyl forms a hydrogen bond with His41 and a covalent bond with Cys44 of Mpro. Interestingly, ebselen also forms a covalent bond with Cys145 and hydrogen bond with Glu166 (Fig. 1B) in the binding pocket that is consisted of residues His41, Met49, Phe140, Cys145, Ser144, His163, Met165 and Glu166. Both docking models indicate that the free benzene ring of ebselen is unlikely to possess molecular interactions towards Mpro. Therefore, introducing hydrogen bond donor group (amino, hydroxy and carboxyl) or hydrogen bond receptor group (carbonyl, methoxyl and fluoro groups) may increase the non-covalent interaction between ebselen derivatives and Mpro for enhancement of inhibitory effect.

Based on the docking that introducing substituents at benzene rings of ebselen may improve the activity of ebselen to Mpro, we synthesized a series of ebselen derivatives (EBs) through introducing different substituents at $N$-position aimed at increasing the antiviral activity on SARS-CoV-2 (Scheme 1). The A series maintained the benzene group at N1 position. We chose a series of substituent group with different electrostatic potentials and electron density distribution, such as amino, hydroxy, methoxy, trifluoromethyl and halogen at para- or meta-position. The B series used pyridine with lower electron density distribution to replace the benzene. Combined with the substitution at ortho-, paraor meta-position, B series can effectively reduce the formation of covalent selenosulfide bond. Most of EBs were synthesized according to Scheme 2, and the synthesis routes of the other EBs were shown in Schemes 3 and 4.

\subsection{Inhibition of Mpro by ebselen derivatives in FRET assay and HPLC assay}

We first evaluated the inhibitory effect of ebselen on Mpro using Mpro proteins purified under Ni-NTA column with 90\% purity in FRET assay (Figure S1). Ebselen showed a concentration-dependent inhibition of Mpro with an $\mathrm{IC}_{50}$ value of $0.41 \mu \mathrm{M}$, consistent with previous observation for ebselen with an $\mathrm{IC}_{50}$ of $0.67 \mu \mathrm{M}$ [14]. Further evaluating ebselen derivatives (EBs) at a single concertation $(0.3 \mu \mathrm{M})$ revealed that EB2-1, 2-3, 2-7, 2-9, 2-10, 2-11, 2-14, 2-16, 2-17, 2-18 and 2-19 showed stronger inhibition on Mpro than ebselen (Table 1 and Table 2).
We further used the HPLC assay to verify the inhibitory effect of EBs on Mpro that digests its substrate SARS-CoV-2 Mpro MCA-AVLQSGFRLys(Dnp)-Lys- $\mathrm{NH}_{2}$. As compared with control without Mpro (Figure S2Aa), the substrate was hydrolyzed about 70\% in the presence of Mpro $(0.2 \mu \mathrm{M})$ due to its enzymatic cleavage (Figure S2Ab). In contrast, adding ebselen $(0.3 \mu \mathrm{M})$ attenuated the substrate hydrolysis to $30 \%$ by inhibiting the Mpro cleavage (Figure S2Ac). We further evaluated the inhibitory effect of EBs on Mpro activity. As shown in Figure S2Ad-z, some EBs at $0.3 \mu \mathrm{M}$ showed a significant attenuation of the substrate hydrolysis with an increased AUC by inhibiting Mpro. These results demonstrate the stronger inhibitory effects of EBs on Mpro as compared with ebselen.

To further confirm the inhibition of EBs at one concentration on Mpro, we carried out a dose-dependent inhibition of Mpro by EBs in FRET assay. As shown in Figure S3, these identified hits exhibited a dose-dependent inhibition of Mpro activity with $\mathrm{IC}_{50}$ values ranging from 0.07 to $0.59 \mu \mathrm{M}$. Among these derivatives, EB2-19 exhibited the most potent inhibition on Mpro.

Small molecules can self-associate into colloidal aggregates that inhibit enzymes and other proteins at micromolar concentrations in nonspecific fashion [32]. Therefore, we performed the detergent-based assay to distinguish these ebselen derivatives from aggregate-based inhibitors. Adding $0.01 \%$ Triton X-100 had no obvious influence on the dose-dependent inhibition of Mpro by either ebselen or EBs, indicating that the EBs function as Mpro inhibitors rather than aggregators (Figure S3).

To evaluate the effect of reducing reagent DTT on enzymatic inhibition of Mpro by ebselen, $4 \mathrm{mM}$ DTT was added in HPLC assay and FRET assay. As shown in Figure S4 and S5, the addition of DTT decreased the inhibitory effect of ebselen and its derivatives on Mpro and increased the hydrolysis of the substrate in HPLC assay. Similarly, DTT also led to the right shift of dose-dependent curves in FRET assay (Figure S6).

\subsection{Cellular antiviral activity of ebselen derivatives}

To investigate the effect of EBs on SARS-CoV-2 viral replication, we determined the complementary RNA copy number of SARS-CoV-2 virus in the infected HPAepiC cells after treatment of 11 ebselen derivatives (EB2-1, 2-3, 2-7, 2-9, 2-10, 2-11, 2-14, 2-16, 2-17, 2-18 and 2-19) at single concentration of $10 \mu \mathrm{M}$ and found that $10 \mu \mathrm{M} \mathrm{EB2-7,2-9}$ and 2-19 inhibited the viral replication in HPAepiC cells. As shown in Figure S7, EB2-7, EB2-9 and EB2-19 dose-dependently inhibited the replication of SARS-CoV-2 with $\mathrm{IC}_{50}$ of $4.07 \mu \mathrm{M}, 19.91 \mu \mathrm{M}$ and $8.23 \mu \mathrm{M}$, as compared with ebselen at $24.60 \mu \mathrm{M}$ in infected HPAepiC cells. The three ebselen derivatives (EB2-7, 2-9 and 2-19) were also the most potent Mpro inhibitors, suggesting that inhibiting Mpro activity can lead to potential discovery of SARS-CoV-2 antiviral drugs. Ebselen derivatives with 3-methoxyphenyl, 3-fluorophenyl and 3-fluoropyridin-4yl showed stronger antiviral activity than ebselen, demonstrating that
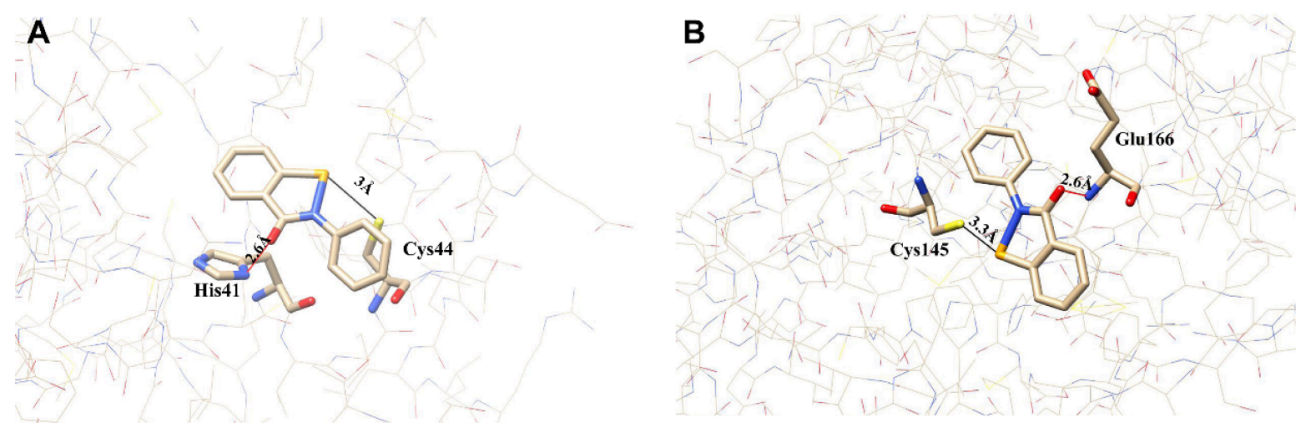

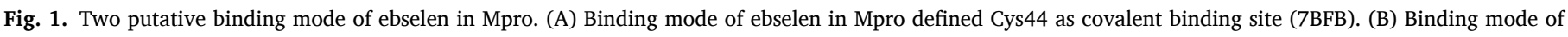
ebselen in Mpro defined Cys145 as covalent binding site(7BAJ). Line: covalent bonds (in black); hydrogen bond (in red). 
<smiles>O=c1c2ccccc2[se]n1-c1ccccc1</smiles>

Ebselen

Series A

$\mathrm{R}_{1}=$ 4-aminophenyl, $\mathrm{R}_{2}=\mathrm{H}$ (EB 2-1)

$\mathrm{R}_{1}=3$-aminophenyl, $\mathrm{R}_{2}=\mathrm{H}$ (EB 2-3)

$R_{1}=3$-trifluoromethylphenyl, $R_{2}=H$ (EB 2-5)

$\mathrm{R}_{1}=4$-phenoxybenzene, $\mathrm{R}_{2}=\mathrm{H}$ (EB 2-6)

$\mathrm{R}_{1}=$ 3-methoxyphenyl, $\mathrm{R}_{2}=\mathrm{H}$ (EB 2-7)

$R_{1}=$ 2-hydroxyphenyl, $R_{2}=H$ (EB 2-8)

$R_{1}=3$-fluorophenyl, $R_{2}=H(E B$ 2-9)

$R_{1}=$ 4-fluorophenyl, $R_{2}=H(E B$ 2-10)

$R_{1}=2$-hydroxyphenyl, $R_{2}=H(E B$ 2-11)

$\mathrm{R}_{1}=$ 3-methoxyphenyl, $\mathrm{R}_{2}=\mathrm{H}$ (EB 2-12)

$R_{1}=$ 4-chlorophenyl, $R_{2}=H$ (EB 2-13)

$\mathrm{R}_{1}=\mathrm{Ph}, \mathrm{R}_{2}=4$-amino (EB 2-14)

$R_{1}=P h, R_{2}=5$-amino (EB 2-20)<smiles>[R]c1ccc2[se]n([R])c(=O)c2c1</smiles>

EBs

Scheme1. Structure of ebselen and its newly synthesized derivatives.

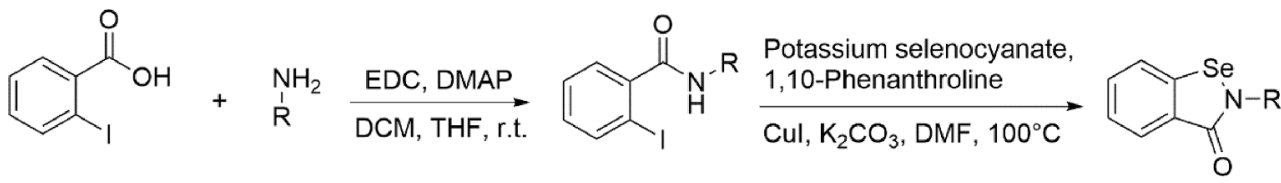

$\mathrm{R}=4$-aminophenyl $(\mathrm{EB} 2-1)$

3-aminophenyl (EB 2-3)

3-trifluoromethylphenyl (EB 2-5)

4-phenoxybenzene (EB 2-6)

3-methoxyphenyl (EB 2-7)

2-hydroxyphenyl (EB 2-8)

4-fluorophenyl (EB 2-10)

\section{Series B}

$\mathrm{R}_{1}=$ pyridine-3-yl, $\mathrm{R}_{2}=\mathrm{H}$ (EB 2-15)

$\mathrm{R}_{1}=$ pyridine $-4-\mathrm{yl}, \mathrm{R}_{2}=\mathrm{H}$ (EB 2-16)

$\mathrm{R}_{1}=$ 2-chloropyridine-4-yl, $\mathrm{R}_{2}=\mathrm{H}(\mathrm{EB} 2-17)$

$\mathrm{R}_{1}=$ 3-methylpyridine-4-yl, $\mathrm{R}_{2}=\mathrm{H}$ (EB 2-18)

$R_{1}=3$-fluoropyridine-4-yl, $R_{2}=H(E B$ 2-19)

$\mathrm{R}_{1}=2$-methylpyridine-4-yl, $\mathrm{R}_{2}=\mathrm{H}$ (EB 2-21)

$\mathrm{R}_{1}=4$-methylpyridine-2-yl, $\mathrm{R}_{2}=\mathrm{H}(\mathrm{EB} 2-22)$

$\mathrm{R}_{1}=5$-aminopyridine-3-yl, $\mathrm{R}_{2}=\mathrm{H}$ (EB 2-23)

$\mathrm{R}_{1}=6$-aminopyridine-2-yl, $\mathrm{R}_{2}=\mathrm{H}$ (EB 2-24)

$\mathrm{R}_{1}=$ 2-methoxypyridine-4-yl, $\mathrm{R}_{2}=\mathrm{H}$ (EB 2-25)

Scheme 2. Synthesis of EBs (Except EB 2-9, 2-14, 2-20, 2-21).<smiles>O=C(O)c1cc[n+]([O-])cc1I</smiles><smiles>Nc1ccccc1</smiles><smiles>O=C(Nc1ccccc1)c1ccc([N+](=O)[O-])cc1I</smiles><smiles>[R]1CCCCC1</smiles><smiles>Nc1ccc(I)c(C(=O)Nc2ccccc2)c1</smiles><smiles></smiles><smiles>C=CC</smiles>

EB 2-14, EB 2-20

Scheme 3. Synthesis of EB 2-14 and EB 2-20. (a) EDC, DMAP, DCM, THF, r.t. (b) Fe, $\mathrm{NH}_{4} \mathrm{Cl}_{1} \mathrm{H}_{2} \mathrm{O}$, EtOH, reflux. (c) Potassium selenocyanate, 1,10-Phenanthroline, $\mathrm{CuI}, \mathrm{K}_{2} \mathrm{CO}_{3}$, DMF, $100{ }^{\circ} \mathrm{C}$.

substituting methoxy or fluoro group of ebselen increases the inhibition of Mpro activity through non-covalent interactions. We also examined the safely profile of ebselen derivatives (EB2-1, 2-3, 2-7, 2-9, 2-10, $2-11,2-14,2-16,2-17,2-18$ and 2-19) on HPAepiC cells in MTT assay. As shown in Table S1 and Figure S8, these eleven potent Mpro inhibitors had no obvious cytotoxicity in HPAepiC cells at $100 \mu \mathrm{M}$ for $24 \mathrm{~h}$, suggesting a less safety liability of these compounds.

\subsection{Reduction of Se activity by ebselen derivatives}

Ebselen reacts with the thiol (RSH) of Mpro for formation of a selenenyl sulfide [28]. Ebselen is also a well-known anti-inflammatory agent with glutathione peroxidase-like activity in living cells through reacting with intracellular reactive oxygen species (ROS) for the formation of selenoxide [33], thus likely reducing an available amount of ebselen derivatives and subsequently reducing their antiviral activity in vivo. After confirming that EB2-7, 2-9 and 2-19 had promising antiviral 


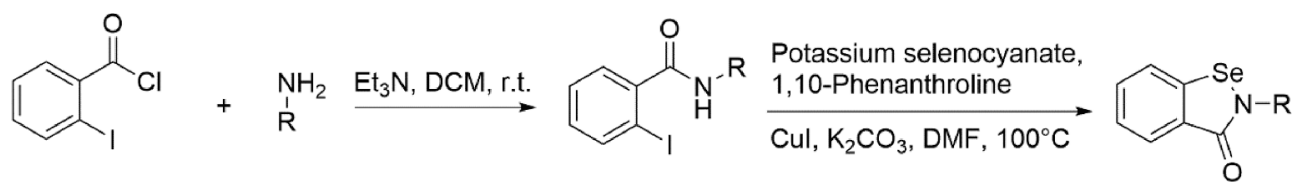

$R=$ 3-fluorophenyl (EB 2-9) 3-methyl-4-pyridine (EB 2-21)

Scheme 4. Synthesis of EB 2-9 and EB 2-21.

\section{Table 1}

Inhibition of SARS-CoV-2 Mpro by ebselen and its derivatives containing a substitution group at the phenyl ring in FRET assay. Data are presented as the means \pm SEM with 3 replicates.<smiles>[R]n1[se]c2ccncc2c1=O</smiles>

\begin{tabular}{|c|c|c|c|}
\hline Entry & $\mathrm{R}_{1}$ & $\mathrm{R}_{2}$ & \%Inhibition@0.3 $\mu \mathrm{M}$ \\
\hline Ebselen & $\mathrm{H}$ & $\mathrm{Ph}$ & $61.21 \pm 0.76$ \\
\hline EB2-1 & H & & $71.60 \pm 0.69$ \\
\hline EB2-3 & $\mathbf{H}$ & & $68.65 \pm 0.39$ \\
\hline EB2-5 & $\mathrm{H}$ & & $19.23 \pm 0.52$ \\
\hline EB2-6 & $\mathrm{H}$ & & $50.06 \pm 0.62$ \\
\hline EB2-7 & H & & $67.28 \pm 0.14$ \\
\hline EB2-8 & $\mathrm{H}$ & & $56.26 \pm 0.46$ \\
\hline EB2-9 & $\mathbf{H}$ & & $71.63 \pm 0.39$ \\
\hline EB2-10 & $\mathbf{H}$ & & $67.00 \pm 0.47$ \\
\hline EB2-11 & H & & $77.68 \pm 0.60$ \\
\hline EB2-12 & $\mathrm{H}$ & & $55.25 \pm 0.76$ \\
\hline EB2-13 & $\mathrm{H}$ & & $49.23 \pm 0.88$ \\
\hline EB2-14 & 4-amino & $\mathbf{P h}$ & $63.67 \pm 0.75$ \\
\hline EB2-20 & 5-amino & $\mathrm{Ph}$ & $47.00 \pm 1.66$ \\
\hline
\end{tabular}

Note: bold number denotes an improved inhibition than ebselen in FRET assay.

activity, we further tested the ROS reactivity of these three Mpro inhibitors using a 2,7-dichloro-fluorescein diacetate (DCFH-DA) fluorescent probe by detecting the level of intracellular ROS. As shown in Fig. 2, adding $\mathrm{H}_{2} \mathrm{O}_{2}$ induced the highest level of ROS and caused oxidative and free radical damage in HPAepiC cells. The preincubation of $10 \mathrm{mM}$ NAC (an ROS scavenger) for $1 \mathrm{~h}$ scavenged the intracellular ROS and reversed the cytotoxicity induced by ROS. With the addition of ebselen and EBs, fluorescence levels and cell death were dramatically decreased as compared to the $\mathrm{H}_{2} \mathrm{O}_{2}$ group. As shown in Fig. 2B and C, EB2-7 and 2-9 exhibited a much weaker effect on ROS scavenging than ebselen, suggesting that these two compounds may exert a higher antiviral activity in vivo.
Table 2

Inhibition of SARS-CoV-2 Mpro by ebselen derivatives containing a pyridine ring in FRET assay. Data are presented as the means \pm SEM with 3 replicates.<smiles></smiles>

\begin{tabular}{|c|c|c|}
\hline Entry & $\mathrm{R}$ & \%Inhibition @0.3 $\mu \mathrm{M}$ \\
\hline EB2-15 & & $49.93 \pm 0.88$ \\
\hline EB2-16 & & $66.02 \pm 0.65$ \\
\hline EB2-17 & & $74.04 \pm 0.55$ \\
\hline EB2-18 & & $75.08 \pm 0.30$ \\
\hline EB2-19 & & $93.72 \pm 0.01$ \\
\hline EB2-21 & & $59.24 \pm 0.42$ \\
\hline EB2-22 & & $14.61 \pm 2.50$ \\
\hline EB2-23 & & $41.66 \pm 0.80$ \\
\hline EB2-24 & & $46.94 \pm 0.48$ \\
\hline EB2-25 & & $29.70 \pm 2.50$ \\
\hline
\end{tabular}

Note: bold number denotes an improved inhibition than ebselen in FRET assay.

\subsection{Proposed interaction between ebselen derivatives and Mpro}

Molecular docking of ebselen derivatives (EB2-7, EB2-9, EB2-19) revealed an increased bond length from $2.3 \AA$ (Se-S bond) to $4.7 \AA$, $3.5 \AA$ and $3.5 \AA$, respectively, between the Se atom of ebselen derivatives and the Cys44 of Mpro, suggesting a non-covalent formation between ebselen derivatives and Mpro (Fig. 3). And hydrogen bonds were formed between the carbonyl group of EB2-7, EB2-9 and EB2-19 and their surrounding His41 and Ser46, indicating that these residues might be essential to maintain their inhibitory activity on Mpro (Fig. 3). To further confirm the binding of ebselen derivatives to Mpro, we used LCMS/MS analysis to capture residues modified by ebselen or EB2-7. As shown in Figure S9, a short peptide (GLWLDDVVYCPRHVICTSEDMLNPNYEDLLI) containing the Cys44 of Mpro was identified to bind to ebselen, but not EB2-7 (Figure S10), indicating that it is a noncovalent inhibitor.

\subsection{Molecular docking and structure-activity relationship analysis}

Based on the Mpro inhibitory activity of ebselen derivatives and LCMS/MS analysis, a structure-activity relationship was analyzed based on molecular docking studies. EB2-7, 2-9 and 2-19 were the most potent 
A

Control

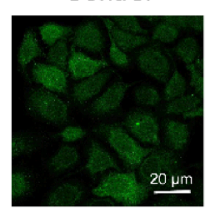

B
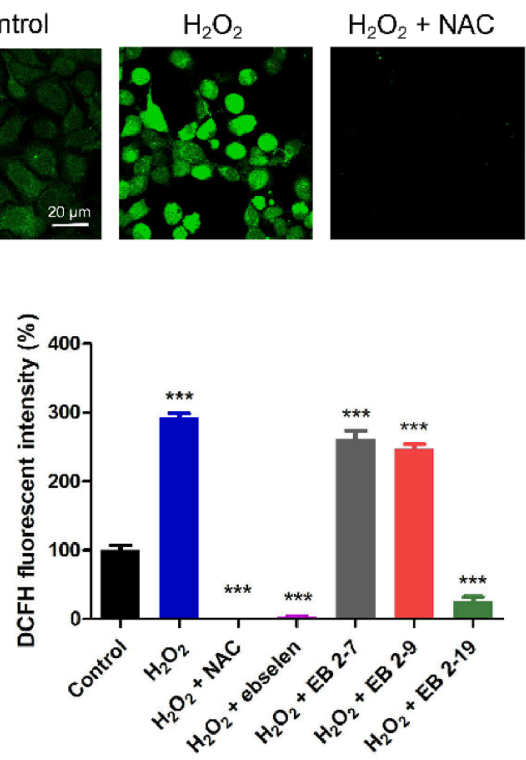

Fig. 2. Inhibition of $\mathrm{H}_{2} \mathrm{O}_{2}$ induced intracellular reactive oxygen species (ROS) production by $10 \mu \mathrm{M}$ EBs. (A) Confocal imaging of ROS generation induced by $50 \mu \mathrm{M}$ $\mathrm{H}_{2} \mathrm{O}_{2}$ in HPAepiC cells by DCFH-DA. (B) Relative change of fluorescence intensity detected by DCFH-DA under confocal imaging. (C) The effect of EBs on ROS induced cell death. Excitation: $488 \mathrm{~nm}$, and emission: 520-570 nm. Scale bar, $20 \mu \mathrm{m}$. The data are presented as the means \pm SEM from five replicates (n $=5$ ). NAC ( $N$-Acetyl-L-cysteine, $10 \mathrm{mM}$ ). ${ }^{* * *} P<0.001$, compared with control group.
C

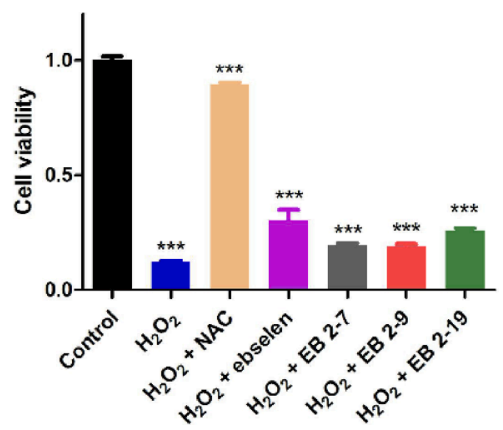

B
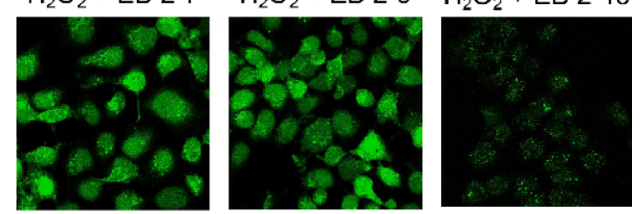
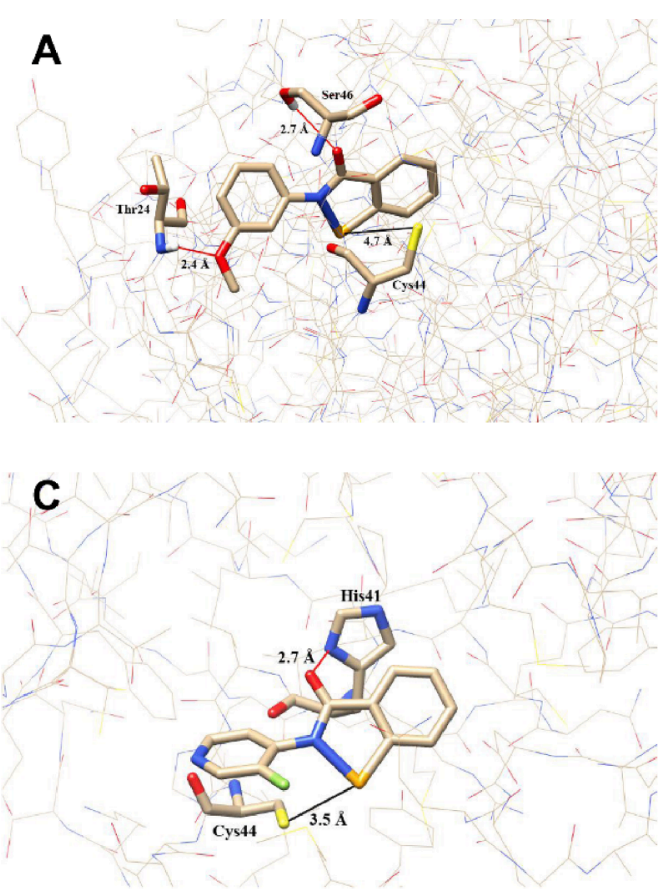
Figure S11, the bond distances between Se atom of EB2-1, EB2-3, EB214 , EB2-20 and Cys44 of Mpro were $3.4 \AA$, $3.6 \AA$, $4.3 \AA$ and $4.6 \AA$, respectively. The amino groups of EB2-1, 2-3 and 2-14 can form hydrogen interaction with surrounding Thr25 of Mpro but not EB2-20, indicating that EB2-20 had a relatively weaker inhibitory effect on Mpro (Table 1).

Molecular docking of EB2-5, EB2-6 and EB2-8 (substitution at metaposition) defines their binding to the binding pocket of Mpro. As shown in Figure S12, compared to EB2-6 and EB2-8, no hydrogen bond was observed between carbonyl group of EB2-5 and His41 of Mpro due to steric hindrance of trifluoromethyl group, which may explain its dramatic decrease of inhibitory activity (Table 1). EB2-10, EB2-11, EB2-12 and EB2-13 (substitution at para-position) are shown to share a similar pose in the binding pocket of ebselen in Mpro (Figure S13). The bond distance between the Se atom of these four compounds and the Cys44 of Mpro was about 3.2-3.6 $\AA$ and the hydrogen bonds between the carbonyl group and the His 41 of Mpro are critical for maintaining the antiviral activity of ebselen derivatives such as EB2-10, EB2-11, EB2-12 and EB2-13.

Ebselen derivatives containing pyridine ring without substitution (EB2-15 and 2-16) show similar pose in the binding picket of Mpro (Figure S14). However, EB2-16 (pyridin-4-yl) exhibited a higher inhibitory effect on Mpro. Therefore, the subsequent studies were focused on substituting the pyridine ring of EB2-16. Substitution at metaposition with methyl (EB2-18) and fluorine (EB2-19) leads to an improvement of inhibitory activity compared to EB2-16 (Table 2). As shown in Figure S14 and S15 EB2-16, 2-18, and 2-19 showed a similar pose in the binding pocket. In contrast, substitution at ortho-position (EB2-21 and 2-25) was not helpful to the improvement of activity (Table 2 and Figure S16).

In general, our docking reveals that ebselen derivatives can fit into the binding pocket of Mpro with a similar pose to ebselen, and the formation of hydrogen bonds with the His 41 is essential to maintain the inhibition of Mpro by these compounds. The residues Thr24, Thr25, Val42 and Ser46 are important in mediating the molecular interactions with the substitutions of ebselen for improvement of Mpro inhibition by ebselen.

\section{Conclusion}

In conclusion, we designed and synthesized a series of ebselen derivatives based on our docking that substituting critical groups of ebselen for reducing steric hindrance through a noncovalent binding to Mpro for improvement of antiviral activity. Two candidates EB2-7 and 2-19 exhibite potent antiviral activity with six-fold and three-fold improved potency, respectively, better than their prototype ebselen. Ebselen derivative EB2-7 may hold a promise as an antiviral agent with repurposing potential against SARS-CoV-2 virus.

\section{Methods and materials}

\subsection{Synthetic details}

All raw materials were obrained from TCI, Sinopharm Chemical Reagent Company, Bide pharmatech, Energy Chemical, Sigma Aldrich. Bruker AVANCE III HD $400 \mathrm{MHz}$ was applied to obtain ${ }^{1} \mathrm{H}$ NMR (400 $\mathrm{MHz})$ and ${ }^{13} \mathrm{C}$ NMR (101 MHz) spectra, solvent and internal standard were d6-DMSO and tetramethylsilane (TMS), respectively.

\subsection{Chemistry}

\subsubsection{General procedure for synthesis of benzamide}

The syntheses of corresponding benzamide were shown in Scheme 1 , 2 and 3. 2-iodobenzoic acid ( $1 \mathrm{mmol}, 248 \mathrm{mg}$ ) were dissolved in $10 \mathrm{~mL}$ DCM and $2.5 \mathrm{~mL}$ THF, then DMAP (0.2 mmol, $24.4 \mathrm{mg})$, amine (1.1 $\mathrm{mmol})$ and EDC (1.4 mmol, $267 \mathrm{mg}$ ) were added into the solution subsequently. After the mixture solution was kept stirring for $12 \mathrm{~h}$ at $25{ }^{\circ} \mathrm{C}$. Ethyl acetate was used to extract the reaction solution. The organic phase was combined and dried with anhydrous magnesium sulfate, followed by removal of the solvent by rotary evaporation, and the crude product was purified by silica gel chromatography to obtain purified product.

2-iodo-4-nitrobenzoic acid or 2-iodo-5-nitrobenzoic acid $(1 \mathrm{mmol}$, $293 \mathrm{mg}$ ) were added into a round flask containing $10 \mathrm{~mL} \mathrm{DCM}$ and 2.5 $\mathrm{mL}$ THF, then DMAP $(0.2 \mathrm{mmol}, 24.4 \mathrm{mg})$, aniline (1.1 mmol, $111 \mathrm{mg}$ ) and EDC (1.4 mmol, $267 \mathrm{mg}$ ) were added into the flask subsequently. After the reaction solution was kept stirring for $12 \mathrm{~h}$ at $25^{\circ} \mathrm{C}$. Ethyl acetate was used to extract the reaction solution. The organic phase was combined and dried with anhydrous magnesium sulfate, followed by removal of the solvent by rotary evaporation, and the crude product was purified by silica gel chromatography to obtain 2-iodo-5-nitro- $N$-phenylbenzamide product.

2-iodo-5-nitro- $N$-phenylbenzamide $(0.5 \mathrm{mmol}, 184 \mathrm{mg})$ was dissolved in the mixture solvent of EtOH and $\mathrm{H}_{2} \mathrm{O}$, into which iron powder (2.1 mmol, $115 \mathrm{mg}$ ) and ammonium chloride (1 mmol, $54 \mathrm{mg}$ ) were added. After the reaction solution was kept reflux for $8 \mathrm{~h}$, iron powder was removed through filtration and solvents were evaporated under reduced pressure. The crude product was purified by column chromatography to obtain target compound.

2-iodobenzoyl chloride ( $300 \mathrm{mg}, 1$ equiv) was taken into a roundbottom flask, then $1 \mathrm{~mL}$ DCM was added to dissolved the solid. Amine (1.2 mmol) and $\mathrm{Et}_{3} \mathrm{~N}$ (341 mg, 3 equiv) were mixed in $1 \mathrm{~mL} \mathrm{DCM}$, and the mixture was dropwise added into the reaction flask. The reaction was stirred for $12 \mathrm{~h}$ at $25^{\circ} \mathrm{C}$. After completed, the solvent was removed by rotary evaporation, and the crude product was purified by silica gel chromatography to obtain purified product.

\subsubsection{General procedure for synthesis of ebselen derivatives [34]}

The syntheses of ebselen derivatives were shown in Scheme 1,2 and 3. The starting benzamide $(1.3 \mathrm{mmol})$, cesium carbonate $(3.25 \mathrm{mmol})$, CuI (1.95 mmol), 1,10-phenanthroline (1.95 mmol), and KSeCN (1.56 mmol) were taken into a round-bottom flask. The round-bottom flask was purged with nitrogen. Then $\mathrm{N}, \mathrm{N}$-dimethylmethanamide was added as solvent, and stirred at $100{ }^{\circ} \mathrm{C}$ for $1 \mathrm{~h}$. After the reaction completed, the reaction mixture was filtered to remove precipitate. The filtrate was extracted with ethyl acetate and washed with $\mathrm{H}_{2} \mathrm{O}$ to remove $N, N$ dimethylmethanamide. The organic phase was combined and dried with anhydrous magnesium sulfate, followed by removal of the solvent by rotary evaporation. The crude product was purified by silica gel chromatography to obtain purified product.

4.2.2.1. Synthesis of EB 2-1. $N$-(4-aminophenyl)-2-iodobenzamide ( $439 \mathrm{mg}, 1.3 \mathrm{mmol}$ ) was used as starting benzamide. Purified product: yellow solid (80 mg, 21\%). ${ }^{1} \mathrm{H}$ NMR (400 MHz, DMSO-d6) $\delta 8.05$ (d, $J=$ $7.9 \mathrm{~Hz}, 1 \mathrm{H}), 7.85$ (dd, $J=7.8,0.9 \mathrm{~Hz}, 1 \mathrm{H}), 7.68-7.62$ (m, 1H), $7.49-$ $7.43(\mathrm{~m}, 1 \mathrm{H}), 7.19-7.14(\mathrm{~m}, 2 \mathrm{H}), 6.63-6.58(\mathrm{~m}, 2 \mathrm{H}), 5.25(\mathrm{~s}, 2 \mathrm{H}) .{ }^{13} \mathrm{C}$ NMR (101 MHz, DMSO-d6) $\delta 165.29$ (s), 147.96 (s), 139.50 (s), 132.22 (s), 128.85 (s), 128.21 (s), 127.92 (s), 127.09 (s), 126.51 (s), 126.18 (s), 114.24 (s). MS: $m / z[\mathrm{M}+\mathrm{H}]^{+}$calcd for $\mathrm{C}_{13} \mathrm{H}_{10} \mathrm{~N}_{2}$ OSe: 290.9958 , found: 290.9960 .

4.2.2.2. Synthesis of EB 2-3. $N$-(3-aminophenyl)-2-iodobenzamide (439 mg, $1.3 \mathrm{mmol}$ ), was used as starting benzamide. Purified product: yellow solid (271 mg, 72\%). ${ }^{1} \mathrm{H}$ NMR (400 MHz, DMSO-d6) $\delta 8.07$ (d, $J$ $=7.9 \mathrm{~Hz}, 1 \mathrm{H}), 7.89(\mathrm{dd}, J=7.8,0.8 \mathrm{~Hz}, 1 \mathrm{H}), 7.70-7.64(\mathrm{~m}, 1 \mathrm{H}), 7.50-$ $7.44(\mathrm{~m}, 1 \mathrm{H}), 7.07$ (t, $J=8.0 \mathrm{~Hz}, 1 \mathrm{H}), 6.87(\mathrm{t}, J=2.1 \mathrm{~Hz}, 1 \mathrm{H}), 6.77$ (ddd, $J=7.9,2.1,0.8 \mathrm{~Hz}, 1 \mathrm{H}), 6.47$ (ddd, $J=8.0,2.1,0.9 \mathrm{~Hz}, 1 \mathrm{H}$ ), 5.31 (s, 2H). ${ }^{13} \mathrm{C}$ NMR (101 MHz, DMSO-d6) $\delta 165.14$ (s), 150.00 (s), $140.76(\mathrm{~s})$, 139.36 (s), 132.51 (s), 129.88 (s), 129.29 (s), 128.32 (s), 126.63 (s), 126.19 (s), 112.37 (s), 112.12 (s), 110.38 (s). MS: $m / z[\mathrm{M}+\mathrm{H}]^{+}$calcd for $\mathrm{C}_{13} \mathrm{H}_{10} \mathrm{~N}_{2} \mathrm{OSe}$ : 290.9958, found: 290.9947. 
4.2.2.3. Synthesis of EB 2-5. 2-iodo- $N$-(3-(trifluoromethyl)phenyl)benzamide (508 mg, $1.3 \mathrm{mmol}$ ) was used as starting benzamide. Purified product: white solid (267 mg, 60\%). ${ }^{1} \mathrm{H}$ NMR (400 MHz, DMSO-d6) $\delta$ 8.20 (s, 1H), 8.11 (d, $J=8.0 \mathrm{~Hz}, 1 \mathrm{H}), 7.94$ (dd, $J=7.7,0.9 \mathrm{~Hz}, 1 \mathrm{H}), 7.85$ (d, $J=9.7 \mathrm{~Hz}, 1 \mathrm{H}), 7.75-7.69(\mathrm{~m}, 2 \mathrm{H}), 7.63(\mathrm{~d}, J=7.9 \mathrm{~Hz}, 1 \mathrm{H}), 7.54-$ 7.49 (m, 1H). ${ }^{13} \mathrm{C}$ NMR (101 MHz, DMSO-d6) $\delta 165.94(\mathrm{~s}), 141.10(\mathrm{~s})$, 139.28 (s), 133.12 (s), 131.10 (s), 130.07 (s), 128.88 - 128.47 (m), 126.91 (s), 126.40 (s), 122.52 (s), 121.10 (d, $J=4.0 \mathrm{~Hz}$ ). MS: $m / z$ $[\mathrm{M}+\mathrm{H}]^{+}$calcd for $\mathrm{C}_{14} \mathrm{H}_{18} \mathrm{~F}_{3} \mathrm{NOSe}$ : 343.9723, found: 343.9427 .

4.2.2.4. Synthesis of EB 2-6. 2-iodo- $N$-(4-phenoxyphenyl)benzamide (540 mg, $1.3 \mathrm{mmol}$ ) was used as starting benzamide. Purified product: brown solid (157 mg, 33\%). ${ }^{1} \mathrm{H}$ NMR (400 MHz, DMSO-d6) $\delta 8.10$ (d, $J$ $=8.0 \mathrm{~Hz}, 1 \mathrm{H}), 7.91(\mathrm{dd}, J=7.7,0.7 \mathrm{~Hz}, 1 \mathrm{H}), 7.72-7.66(\mathrm{~m}, 1 \mathrm{H}), 7.66-$ $7.61(\mathrm{~m}, 2 \mathrm{H}), 7.52-7.46(\mathrm{~m}, 1 \mathrm{H}), 7.46-7.40$ (m, 2H), 7.17 (t, $J=7.4$ $\mathrm{Hz}, 1 \mathrm{H}), 7.08$ (td, $J=7.9,1.5 \mathrm{~Hz}, 4 \mathrm{H}) .{ }^{13} \mathrm{C}$ NMR (101 MHz, DMSO-d6) $\delta$ 165.50 (s), 157.02 (s), 154.87 (s), 139.37 (s), 135.41 (s), 132.69 (s), 130.52 (d, $J=16.4 \mathrm{~Hz}$ ), 128.80 (s), 128.42 (s), 127.07 (s), 126.74 (s), 126.32 (s), 124.14 (s), 119.57 (s), 119.21 (s). MS: $m / z[\mathrm{M}+\mathrm{H}]^{+}$calcd for $\mathrm{C}_{19} \mathrm{H}_{13} \mathrm{NO}_{2} \mathrm{Se}$ : 368.0112, found: 368.0119 .

4.2.2.5. Synthesis of EB 2-7. 2-iodo- $N$-(3-methoxyphenyl)benzamide (459 mg, $1.3 \mathrm{mmol}$ ) was used as starting benzamide. Purified product: brown solid (139 mg, 35\%). ${ }^{1} \mathrm{H}$ NMR (400 MHz, DMSO-d6) $\delta 8.20$ (d, $J$ $=8.0 \mathrm{~Hz}, 1 \mathrm{H}), 7.90(\mathrm{~d}, J=7.2 \mathrm{~Hz}, 1 \mathrm{H}), 7.70-7.64(\mathrm{~m}, 1 \mathrm{H}), 7.48(\mathrm{t}, J=$ $7.3 \mathrm{~Hz}, 1 \mathrm{H}$ ), $7.39-7.30$ (m, 2H), 7.16 (dd, $J=7.9,1.3 \mathrm{~Hz}, 1 \mathrm{H}$ ), 6.85 (dd, $J=8.2,2.2 \mathrm{~Hz}, 1 \mathrm{H}), 3.79$ (s, 3H). ${ }^{13} \mathrm{C}$ NMR (101 MHz, DMSO-d6) $\delta$ 165.42 (s), 160.13 (s), 141.50 (s), 139.38 (s), 132.60 (s), 130.44 (s), 129.34 (s), 128.31 (s), 126.65 (d, $J=6.4 \mathrm{~Hz}$ ), 117.10 (s), 111.72 (s), 110.77 (s), 55.72 (s). MS: $m / z \quad[\mathrm{M}+\mathrm{H}]^{+}$calcd for $\mathrm{C}_{14} \mathrm{H}_{11} \mathrm{NO}_{2} \mathrm{Se}$ : 305.9955, found: 305.9964 .

4.2.2.6. Synthesis of EB 2-8. $\mathrm{N}$-(3-hydroxyphenyl)-2-iodobenzamide (441 mg, $1.3 \mathrm{mmol}$ ) was used as starting benzamide. Purified product: yellow solid (90 mg, 24\%). ${ }^{1} \mathrm{H}$ NMR (400 MHz, DMSO-d6) $\delta 9.69(\mathrm{~s}, 1 \mathrm{H})$, $8.08(\mathrm{~d}, J=8.0 \mathrm{~Hz}, 1 \mathrm{H}), 7.92-7.88(\mathrm{~m}, 1 \mathrm{H}), 7.71-7.66(\mathrm{~m}, 1 \mathrm{H}), 7.51-$ $7.46(\mathrm{~m}, 1 \mathrm{H}), 7.24(\mathrm{t}, J=8.1 \mathrm{~Hz}, 1 \mathrm{H}), 7.15(\mathrm{t}, J=2.2 \mathrm{~Hz}, 1 \mathrm{H}), 7.05$ (ddd, $J=8.0,2.0,0.8 \mathrm{~Hz}, 1 \mathrm{H}$ ), 6.67 (ddd, $J=8.2,2.3,0.8 \mathrm{~Hz}, 1 \mathrm{H}) .{ }^{13} \mathrm{C}$ NMR (101 MHz, DMSO-d6) $\delta 165.30$ (s), 158.35 (s), 141.19 (s), 139.26 (s), 132.70 (s), 130.38 (s), 129.21 (s), 128.40 (s), 126.72 (s), 126.23 (s), 115.42 (s), 113.41 (s), 111.86 (s). MS: $m / z \quad[\mathrm{M}+\mathrm{H}]^{+}$calcd for $\mathrm{C}_{13} \mathrm{H}_{9} \mathrm{NO}_{2} \mathrm{Se}: 291.9799$, found: 291.9806 .

4.2.2.7. Synthesis of EB 2-9. $N$-(3-fluorophenyl)-2-iodobenzamide ( $443 \mathrm{mg}, 1.3 \mathrm{mmol}$ ) was used as starting benzamide. Purified product: yellow solid (87 mg, 23\%). ${ }^{1} \mathrm{H}$ NMR (400 MHz, DMSO- $d 6$ ) $\delta 8.10$ (d, $J=$ $8.0 \mathrm{~Hz}, 1 \mathrm{H}), 7.92(\mathrm{dd}, J=7.8,0.9 \mathrm{~Hz}, 1 \mathrm{H}), 7.73-7.68(\mathrm{~m}, 2 \mathrm{H}), 7.53-$ 7.47 (m, 2H), $7.45-7.42$ (m, 1H), 7.12 (tdd, $J=8.6,2.6,1.0 \mathrm{~Hz}, 1 \mathrm{H})$. ${ }^{13} \mathrm{C}$ NMR (101 MHz, DMSO-d6) $\delta 165.72$ (s), 163.78 (s), 161.36 (s), 141.97 (d, $J=10.6 \mathrm{~Hz}), 139.24$ (s), 133.02 (s), 131.32 (d, $J=9.5 \mathrm{~Hz}$ ), 128.96 (s), 128.51 (s), 126.85 (s), 126.36 (s), 120.54 (d, $J=2.8 \mathrm{~Hz}$ ), 112.89 (s), 112.68 (s), 111.77 (s), 111.52 (s). MS: $m / z[\mathrm{M}+\mathrm{H}]^{+}$calcd for $\mathrm{C}_{13} \mathrm{H}_{8}$ FNOSe: 293.9755, found: 293.9751 .

4.2.2.8. Synthesis of EB 2-10. N-(4-fluorophenyl)-2-iodobenzamide (443 mg, $1.3 \mathrm{mmol}$ ) was used as starting benzamide. Purified product: white solid (72 mg, 19\%). ${ }^{1} \mathrm{H}$ NMR (400 MHz, DMSO-d6) $\delta 8.09$ (d, $J=$ $8.0 \mathrm{~Hz}, 1 \mathrm{H}), 7.91$ (dd, $J=7.8,0.9 \mathrm{~Hz}, 1 \mathrm{H}), 7.72-7.69$ (m, 1H), 7.66 (ddd, $J=7.1,4.1,1.7 \mathrm{~Hz}, 2 \mathrm{H}), 7.52-7.47$ (m, 1H), $7.33-7.28(\mathrm{~m}, 2 \mathrm{H})$. ${ }^{13} \mathrm{C}$ NMR (101 MHz, DMSO-d6) $\delta 165.58$ (s), 161.40 (s), 158.98 (s), 139.39 (s), 136.35 (s), 132.77 (s), 129.57 (s), 128.68 (s), 128.45 (s), 127.39 (d, $J=8.4 \mathrm{~Hz}$ ), 126.77 (s), 126.34 (s), 116.50 (s), 116.28 (s). MS: $\mathrm{m} / z[\mathrm{M}+\mathrm{H}]^{+}$calcd for $\mathrm{C}_{13} \mathrm{H}_{8} \mathrm{FNOSe}$ 293.9755, found: 293.9751 .

4.2.2.9. Synthesis of EB 2-11. N-(4-hydroxyphenyl)-2-iodobenzamide
(441 mg,1.3 mmol) was used as starting benzamide. Purified product: yellow solid (79 mg, 21\%). ${ }^{1} \mathrm{H}$ NMR (400 MHz, DMSO-d6) $\delta 9.62(\mathrm{~s}, 1 \mathrm{H})$, 8.07 (d, $J=8.0 \mathrm{~Hz}, 1 \mathrm{H}), 7.88$ (dd, $J=7.7,0.9 \mathrm{~Hz}, 1 \mathrm{H}), 7.70-7.64$ (m, $1 \mathrm{H}), 7.50-7.44(\mathrm{~m}, 1 \mathrm{H}), 7.39-7.33(\mathrm{~m}, 2 \mathrm{H}), 6.86-6.81(\mathrm{~m}, 2 \mathrm{H}) .{ }^{13} \mathrm{C}$ NMR (101 MHz, DMSO-d6) $\delta 165.37$ (s), 156.21 (s), 139.48 (s), 132.40 (s), 131.09 (s), 128.79 (s), 128.29 (s), 127.25 (s), 126.60 (s), 126.24 (s), 116.04 (s). MS: $m / z[\mathrm{M}+\mathrm{H}]^{+}$calcd for $\mathrm{C}_{13} \mathrm{H}_{9} \mathrm{NO}_{2} \mathrm{Se}: 291.9799$, found: 291.9793 .

4.2.2.10. Synthesis of EB 2-12. 2-iodo- $N$-(4-methoxyphenyl)benzamide (459 mg,1.3 mmol) was used as starting benzamide. Purified product: yellow solid (119 mg, 30\%). ${ }^{1} \mathrm{H}$ NMR (400 MHz, DMSO-d6) $\delta 8.08$ (d, $J$ $=8.0 \mathrm{~Hz}, 1 \mathrm{H}), 7.89(\mathrm{dd}, J=7.7,0.9 \mathrm{~Hz}, 1 \mathrm{H}), 7.71-7.65(\mathrm{~m}, 1 \mathrm{H}), 7.53-$ $7.46(\mathrm{~m}, 3 \mathrm{H}), 7.05-7.00(\mathrm{~m}, 2 \mathrm{H}), 3.79(\mathrm{~s}, 3 \mathrm{H}) .{ }^{13} \mathrm{C}$ NMR $(101 \mathrm{MHz}$, DMSO-d6) $\delta 165.42$ (s), 157.80 (s), 139.45 (s), 132.71 (s), 132.52 (s), 128.78 (s), 128.34 (s), 127.00 (s), 126.66 (s), 126.27 (s), 114.81 (s), 55.84 (s). MS: $m / z[\mathrm{M}+\mathrm{H}]^{+}$calcd for $\mathrm{C}_{14} \mathrm{H}_{11} \mathrm{NO}_{2} \mathrm{Se}: 305.9955$, found: 305.9955 .

4.2.2.11. Synthesis of EB 2-13. $N$-(4-chlorophenyl)-2-iodobenzamide (464 mg,1.3 mmol) was used as starting benzamide. Purified product: yellow solid (153 mg, 38\%). ${ }^{1} \mathrm{H}$ NMR (400 MHz, DMSO-d6) $\delta 8.10$ (d, $J$ $=8.0 \mathrm{~Hz}, 1 \mathrm{H}), 7.92(\mathrm{dd}, J=7.7,0.9 \mathrm{~Hz}, 1 \mathrm{H}), 7.73-7.67(\mathrm{~m}, 3 \mathrm{H}), 7.54-$ $7.49(\mathrm{~m}, 3 \mathrm{H}) .{ }^{13} \mathrm{C}$ NMR (101 MHz, DMSO-d6) $\delta 165.61(\mathrm{~s}), 139.22(\mathrm{~s})$, 132.92 (s), 130.11 (s), 129.57 (s), 129.11 (s), 128.82 (s), 128.49 (s), 126.83 (s), 126.56 (s), 126.35 (s), 121.37 (s), 40.62 (s), 40.41 (s), 40.20 (s), 39.99 (s), 39.79 (s), 39.58 (s), 39.37 (s). MS: $m / z[M+H]^{+}$calcd for $\mathrm{C}_{13} \mathrm{H}_{8}$ ClNOSe: 309.9460 , found: 309.9465 .

4.2.2.12. Synthesis of EB 2-14. 4-amino-2-iodo- $N$-phenylbenzamide ( $439 \mathrm{mg}, 1.3 \mathrm{mmol}$ ) was used as starting benzamide. Purified product: yellow solid (68 mg, 18\%). ${ }^{1} \mathrm{H}$ NMR (400 MHz, DMSO-d6) $\delta 7.66$ (d, $J=$ $1.1 \mathrm{~Hz}, 1 \mathrm{H}), 7.64(\mathrm{~d}, J=0.9 \mathrm{~Hz}, 1 \mathrm{H}), 7.57(\mathrm{~d}, J=8.4 \mathrm{~Hz}, 1 \mathrm{H}), 7.48-$ $7.43(\mathrm{~m}, 2 \mathrm{H}), 7.27-7.20(\mathrm{~m}, 1 \mathrm{H}), 7.16(\mathrm{~d}, J=2.0 \mathrm{~Hz}, 1 \mathrm{H}), 6.68$ (dd, $J=$ 8.5, $2.0 \mathrm{~Hz}, 1 \mathrm{H}), 6.08$ (s, 2H). ${ }^{13} \mathrm{C}$ NMR (101 MHz, DMSO-d6) $\delta 165.91$ (s), 153.51 (s), 140.88 (d, $J=26.5 \mathrm{~Hz}$ ), 129.46 (d, $J=8.5 \mathrm{~Hz}$ ), 125.27 (s), 124.44 (s), 116.79 (s), 113.61 (s), 108.05 (s). MS: $m / z[\mathrm{M}+\mathrm{H}]^{+}$calcd for $\mathrm{C}_{13} \mathrm{H}_{10} \mathrm{~N}_{2} \mathrm{OSe}: 290.9958$, found: 290.9968 .

4.2.2.13. Synthesis of EB 2-15. 2-iodo- $N$-(pyridin-3-yl)benzamide (421 $\mathrm{mg}, 1.3 \mathrm{mmol}$ ) was used as starting benzamide. Purified product: brown solid (104 mg, 30\%). ${ }^{1} \mathrm{H}$ NMR (400 MHz, DMSO-d6) $\delta 8.89$ (s, 1H), 8.46 (d, $J=3.2 \mathrm{~Hz}, 1 \mathrm{H}), 8.12$ (d, $J=8.1 \mathrm{~Hz}, 1 \mathrm{H}), 8.07$ (ddd, $J=8.2,2.5,1.4$ $\mathrm{Hz}, 1 \mathrm{H}), 7.94$ (dd, $J=7.7,0.8 \mathrm{~Hz}, 1 \mathrm{H}), 7.74-7.68(\mathrm{~m}, 1 \mathrm{H}), 7.55-7.48$ (m, 2H). ${ }^{13} \mathrm{C}$ NMR (101 MHz, DMSO-d6) $\delta 146.89(\mathrm{~s}), 145.89(\mathrm{~s}), 139.50$ (s), 133.06 (s), 132.41 (s), 128.45 (d, $J=17.7 \mathrm{~Hz}$ ), 126.89 (s), 126.47 (s), 124.55 (s). MS: $m / z[M+H]^{+}$calcd for $\mathrm{C}_{12} \mathrm{H}_{8} \mathrm{~N}_{2} \mathrm{OSe}$ : 276.9802, found: 276.9797 .

4.2.2.14. Synthesis of EB 2-16. N-(2-chloropyridin-4-yl)-2-iodobenzamide (465 mg, $1.3 \mathrm{mmol}$ ) was used as starting benzamide. Purified product: white solid (97 mg, 23\%). ${ }^{1} \mathrm{H}$ NMR (400 MHz, DMSO-d6) $\delta 8.40$ (d, $J=5.7 \mathrm{~Hz}, 1 \mathrm{H}), 8.10(\mathrm{t}, J=4.7 \mathrm{~Hz}, 2 \mathrm{H}), 7.95$ (dd, $J=7.8,0.9 \mathrm{~Hz}$, $1 \mathrm{H}), 7.77-7.70(\mathrm{~m}, 2 \mathrm{H}), 7.54-7.49(\mathrm{~m}, 1 \mathrm{H}) .{ }^{13} \mathrm{C}$ NMR $(101 \mathrm{MHz}$, DMSO-d6) $\delta 166.96$ (s), 151.68 (s), 151.21 (s), 150.19 (s), 138.97 (s), 133.90 (s), 128.81 (d, $J=8.4 \mathrm{~Hz}$ ), 127.14 (s), 126.45 (s), 116.65 (s), 116.44 (s). MS: $m / z[\mathrm{M}+\mathrm{H}]^{+}$calcd for $\mathrm{C}_{12} \mathrm{H}_{7} \mathrm{ClN}_{2} \mathrm{OSe}: 276.9802$, found: 276.9808 .

4.2.2.15. Synthesis of EB 2-17. 2-iodo- $N$-(pyridin-4-yl)benzamide (421 $\mathrm{mg}, 1.3 \mathrm{mmol}$ ) was used as starting benzamide. Purified product: yellow solid (83 mg, 23\%). ${ }^{1} \mathrm{H}$ NMR (400 MHz, DMSO-d6) $\delta 8.58(\mathrm{~s}, 2 \mathrm{H}), 8.11$ (d, $J=8.0 \mathrm{~Hz}, 1 \mathrm{H}), 7.94$ (dd, $J=7.8,0.9 \mathrm{~Hz}, 1 \mathrm{H}), 7.85(\mathrm{~d}, J=5.0 \mathrm{~Hz}$, $2 \mathrm{H}), 7.75-7.70(\mathrm{~m}, 1 \mathrm{H}), 7.54-7.48(\mathrm{~m}, 1 \mathrm{H}) .{ }^{13} \mathrm{C} \mathrm{NMR}(101 \mathrm{MHz}$, DMSO-d6) $\delta 166.56$ (s), 151.15 (s), 147.77 (s), 138.82 (s), 133.58 (s), 
129.18 (s), 128.64 (s), 127.03 (s), 126.44 (s). MS: $m / z[\mathrm{M}+\mathrm{H}]^{+}$calcd for $\mathrm{C}_{12} \mathrm{H}_{8} \mathrm{~N}_{2} \mathrm{OSe}$ : 310.9412 , found: 310.9419 .

4.2.2.16. Synthesis of EB 2-18. 2-iodo- $N$-(3-methylpyridin-4-yl)benzamide $(439 \mathrm{mg}, 1.3 \mathrm{mmol}$ ) was used as starting benzamide. Purified product: white solid (117 mg, 31\%). ${ }^{1} \mathrm{H}$ NMR (400 MHz, DMSO-d6) $\delta$ 8.54 (d, $J=30.1 \mathrm{~Hz}, 2 \mathrm{H}$ ), 8.12 (d, $J=8.1 \mathrm{~Hz}, 1 \mathrm{H}$ ), 7.92 (dd, $J=7.7,0.8$ $\mathrm{Hz}, 1 \mathrm{H}), 7.74-7.69(\mathrm{~m}, 1 \mathrm{H}), 7.53-7.48(\mathrm{~m}, 1 \mathrm{H}), 7.35(\mathrm{~d}, J=5.1 \mathrm{~Hz}$, 1H), 2.16 (s, 3H). ${ }^{13} \mathrm{C}$ NMR (101 MHz, DMSO-d6) $\delta 165.39$ (s), 152.43 (s), 148.79 (s), 145.90 (s), 140.81 (s), 132.82 (s), 128.52 (s), 127.51 (s), $126.70\left(\mathrm{~d}, J=18.3 \mathrm{~Hz}\right.$ ), 15.67 (s). MS: $m / z[\mathrm{M}+\mathrm{H}]^{+}$calcd for $\mathrm{C}_{13} \mathrm{H}_{10} \mathrm{~N}_{2} \mathrm{OSe}: 290.9958$, found: 290.9949.

4.2.2.17. Synthesis of EB 2-19. N-(3-fluoropyridin-4-yl)-2-iodobenzamide (445 mg, $1.3 \mathrm{mmol}$ ) was used as starting benzamide. Purified product: white solid (130 mg, 34\%). ${ }^{1} \mathrm{H}$ NMR (400 MHz, DMSO-d6) $\delta$ 8.72 (d, $J=2.7 \mathrm{~Hz}, 1 \mathrm{H}), 8.50$ (d, $J=5.2 \mathrm{~Hz}, 1 \mathrm{H}), 8.11(\mathrm{~d}, J=8.1 \mathrm{~Hz}$, $1 \mathrm{H}), 7.95$ (dd, $J=7.7,1.0 \mathrm{~Hz}, 1 \mathrm{H}$ ), 7.74 (ddd, $J=9.4,7.5,3.3 \mathrm{~Hz}, 2 \mathrm{H}$ ), $7.54-7.49(\mathrm{~m}, 1 \mathrm{H}) .{ }^{13} \mathrm{C}$ NMR (101 MHz, DMSO-d6) $\delta 169.05$ (s), 146.96 (d, $J=5.2 \mathrm{~Hz}$ ), 139.23 (s), 138.32 (s), 138.12 (s), 135.32 (s), 133.20 (d, $J=9.1 \mathrm{~Hz}$ ), 131.19 (s), 129.81 (s), 128.57 (d, $J=16.5 \mathrm{~Hz}$ ), 116.41 (s). MS: $m / z[\mathrm{M}+\mathrm{H}]^{+}$calcd for $\mathrm{C}_{12} \mathrm{H}_{7} \mathrm{FN}_{2}$ OSe: 294.9708 , found: 294.9690 .

4.2.2.18. Synthesis of EB 2-20. 5-amino-2-iodo- $N$-phenylbenzamide (439 mg, $1.3 \mathrm{mmol}$ ) was used as starting benzamide. Purified product: brown solid (75 mg, 20\%). ${ }^{1} \mathrm{H}$ NMR (400 MHz, DMSO-d6) $\delta 7.64-7.58$ (m, $2 \mathrm{H}), 7.40$ (dd, $J=10.7,5.1 \mathrm{~Hz}, 2 \mathrm{H}), 7.18$ (t, $J=7.4 \mathrm{~Hz}, 1 \mathrm{H}), 7.10$ (d, $J=2.4 \mathrm{~Hz}, 1 \mathrm{H}$ ), 6.91 (dd, $J=8.6,2.5 \mathrm{~Hz}, 1 \mathrm{H}), 5.29$ (s, 2H). ${ }^{13} \mathrm{C} \mathrm{NMR}$ (101 MHz, DMSO- $d_{6}$ ) $\delta 165.68$ (s), 147.88 (s), 141.44 (s), 130.67 (s), 129.38 (s), 129.19 (s), 127.45 (s), 125.28 (s), 124.94 (s), 124.57 (s), 119.93 (s), 111.72 (s). MS: $m / z[\mathrm{M}+\mathrm{H}]^{+}$calcd for $\mathrm{C}_{13} \mathrm{H}_{10} \mathrm{~N}_{2} \mathrm{OSe}$ : 290.9958, found: 290.9959 .

4.2.2.19. Synthesis of EB 2-21. 2-iodo- $N$-(2-methylpyridin-4-yl)benzamide (439 mg, $1.3 \mathrm{mmol}$ ) was used as starting benzamide. Purified product: white solid (80 mg, 21\%). ${ }^{1} \mathrm{H}$ NMR (400 MHz, DMSO-d6) $\delta 7.88$ (dd, $J=7.9,1.6 \mathrm{~Hz}, 1 \mathrm{H}), 7.62$ (d, $J=1.7 \mathrm{~Hz}, 1 \mathrm{H}), 7.56$ (dd, $J=5.6,1.8$ $\mathrm{Hz}, 2 \mathrm{H}), 7.48-7.42(\mathrm{~m}, 1 \mathrm{H}), 7.04-6.95(\mathrm{~m}, 2 \mathrm{H}), 2.46(\mathrm{~s}, 3 \mathrm{H}) .{ }^{13} \mathrm{C}$ NMR (101 MHz, DMSO-d $\left.d_{6}\right) \delta 167.19$ (s), 158.98 (s), 158.41 (s), 158.01 (s), 149.84 (s), 134.27 (s), 130.09 (s), 119.72 (s), 118.92 (s), 117.60 (s), 113.68 (s), 112.22 (s), 24.57 (s). MS: $m / z \quad[\mathrm{M}+\mathrm{H}]^{+}$calcd for $\mathrm{C}_{13} \mathrm{H}_{10} \mathrm{~N}_{2} \mathrm{OSe}: 290.9958$, found: 290.9949 .

4.2.2.20. Synthesis of EB 2-22. 2-iodo- $N$-(4-methylpyridin-2-yl)benzamide (439 mg, $1.3 \mathrm{mmol}$ ) was used as starting benzamide. Purified product: yellow solid (103 mg, 27\%). ${ }^{1} \mathrm{H}$ NMR (400 MHz, DMSO- $\left.d_{6}\right) \delta$ 8.07 (dd, $J=7.8,1.5 \mathrm{~Hz}, 1 \mathrm{H}$ ), 7.77 (ddd, $J=8.7,7.3,1.6 \mathrm{~Hz}, 1 \mathrm{H}$ ), 7.50 (d, $J=8.5 \mathrm{~Hz}, 1 \mathrm{H}), 7.31-7.23(\mathrm{~m}, 2 \mathrm{H}), 7.17-7.12(\mathrm{~m}, 1 \mathrm{H}), 7.01(\mathrm{~s}$, 1H), 2.12 (s, 3H). ${ }^{13} \mathrm{C}$ NMR (101 MHz, DMSO-d 6 ) $\delta 161.49$ (s), 150.29 (s), 139.77 (s), 135.79 (s), $128.90-128.39$ (m), 127.77 (d, $J=15.8 \mathrm{~Hz}$ ), 123.04 (s), 115.47 (s), 114.76 (s), 25.74 (s). MS: $m / z[\mathrm{M}+\mathrm{H}]^{+}$calcd for $\mathrm{C}_{13} \mathrm{H}_{10} \mathrm{~N}_{2}$ OSe: 290.9958, found: 290.9951 .

4.2.2.21. Synthesis of EB 2-23. $N$-(5-aminopyridin-3-yl)-2-iodobenzamide (441 mg, $1.3 \mathrm{mmol}$ ) was used as starting benzamide. Purified product: brown solid (87 mg, 23\%). ${ }^{1} \mathrm{H}$ NMR (400 MHz, DMSO- $\left.d_{6}\right) \delta$ $8.60(\mathrm{~d}, J=7.8 \mathrm{~Hz}, 1 \mathrm{H}), 8.08$ (d, $J=2.1 \mathrm{~Hz}, 1 \mathrm{H}), 7.86-7.81(\mathrm{~m}, 1 \mathrm{H})$, 7.75 (d, $J=2.3 \mathrm{~Hz}, 1 \mathrm{H}), 7.61-7.56(\mathrm{~m}, 1 \mathrm{H}), 7.41(\mathrm{t}, J=6.9 \mathrm{~Hz}, 2 \mathrm{H})$, $7.21(\mathrm{t}, J=2.3 \mathrm{~Hz}, 1 \mathrm{H}), 5.50$ (s, $2 \mathrm{H}) .{ }^{13} \mathrm{C}$ NMR (101 MHz, DMSO-d $\left.d_{6}\right) \delta$ 168.32 (s), 159.08 (s), 150.69 (s), 143.36 (s), 139.29 (d, $J=4.9 \mathrm{~Hz}$ ), 131.27 (s), 128.44 (d, $J=18.1 \mathrm{~Hz}$ ), 104.46 (s), 102.16 (s), 93.99 (s). MS: $\mathrm{m} / z[\mathrm{M}+\mathrm{H}]^{+}$calcd for $\mathrm{C}_{12} \mathrm{H}_{9} \mathrm{~N}_{3} \mathrm{OSe}$ : 291.9911, found: 291.9960 .

4.2.2.22. Synthesis of EB 2-24. $N$-(6-aminopyridin-2-yl)-2-iodobenzamide (441 mg,1.3 mmol) was used as starting benzamide. Purified product: brown solid (113 mg, 30\%). ${ }^{1} \mathrm{H}$ NMR (400 MHz, DMSO- $\left.d_{6}\right) \delta$ $8.06(\mathrm{~d}, J=8.0 \mathrm{~Hz}, 1 \mathrm{H}), 7.86(\mathrm{~d}, J=7.1 \mathrm{~Hz}, 1 \mathrm{H}), 7.72(\mathrm{~d}, J=7.6 \mathrm{~Hz}$, $1 \mathrm{H}), 7.67-7.62(\mathrm{~m}, 1 \mathrm{H}), 7.43(\mathrm{dt}, J=7.2,6.2 \mathrm{~Hz}, 3 \mathrm{H}), 6.14$ (d, $J=5.0$ $\mathrm{Hz}, 2 \mathrm{H}) .{ }^{13} \mathrm{C}$ NMR $(101 \mathrm{MHz}$, DMSO-d 6 ) $\delta 164.69(\mathrm{~s}), 158.84(\mathrm{~s}), 150.88$ (s), 140.17 (s), 139.74 (s), 132.74 (s), 131.30 (s), 127.84 (s), 126.29 (s), 126.17 (s), 104.80 (s), 101.11 (s). MS: $m / z \quad[M+H]^{+}$calcd for $\mathrm{C}_{12} \mathrm{H}_{9} \mathrm{~N}_{3} \mathrm{OSe}: 291.9911$, found: 291.9901 .

4.2.2.23. Synthesis of EB 2-25. 2-iodo- $N$-(2-methoxypyridin-4-yl)benzamide ( $460 \mathrm{mg}, 1.3 \mathrm{mmol}$ ) was used as starting benzamide. Purified product: brown solid (163 mg, 41\%). ${ }^{1} \mathrm{H}$ NMR (400 MHz, DMSO- $\left.d_{6}\right) \delta$ 8.05 (d, $J=5.8 \mathrm{~Hz}, 1 \mathrm{H}), 7.74$ (dd, $J=7.4,1.7 \mathrm{~Hz}, 1 \mathrm{H}), 7.45$ (dtd, $J=$ 9.0, 7.4, $1.5 \mathrm{~Hz}, 2 \mathrm{H}$ ), 7.34 (dd, $J=7.6,1.3 \mathrm{~Hz}, 1 \mathrm{H}$ ), 7.24 (dd, $J=5.7$, $1.7 \mathrm{~Hz}, 1 \mathrm{H}), 7.20$ (d, $J=1.5 \mathrm{~Hz}, 1 \mathrm{H}), 3.83(\mathrm{~s}, 3 \mathrm{H}) .{ }^{13} \mathrm{C}$ NMR $(101 \mathrm{MHz}$, DMSO- $\left.d_{6}\right) \delta 167.98(\mathrm{~s}), 165.02(\mathrm{~s}), 148.39(\mathrm{~s}), 147.80$ (s), 138.77 (s), 134.66 (s), 132.18 (s), 131.84 (s), 128.79 (s), 127.86 (s), 109.03 (s), 99.49 (s), 53.62 (s). MS: $m / z[\mathrm{M}+\mathrm{H}]^{+}$calcd for $\mathrm{C}_{13} \mathrm{H}_{10} \mathrm{~N}_{2} \mathrm{O}_{2} \mathrm{Se}$ : 306.9907, found: 306.9916 .

\subsection{Virus lines}

The SARS-CoV-2 strain 107 was obtained from the Guangdong Provincial CDC, Guangdong, China.

\subsection{Expression and purification of SARS-CoV-2 Mpro}

The preparation of SARS-CoV-2 Mpro was performed by Beijing Ambition Biotechnology Co, Ltd. The SARS-CoV-2 Mpro full-length gene (NC_045512) was optimized and synthesized for the adaption of Escherichia coli. The expression plasmid was transformed into Escherichia coli Rosetta (DE3). After the $\mathrm{OD}_{600}$ value of cells reached $0.6,0.5 \mathrm{mM}$ isopropyl-beta-D-thiogalactopyranoside (IPTG) was added into the cell culture and incubated overnight at $23^{\circ} \mathrm{C}$, and then centrifugated at 8000 rmp to harvest the cells. The precipitate was resuspended in $0.02 \mathrm{M}$ $\mathrm{Na}_{2} \mathrm{HPO}_{4} / \mathrm{NaH}_{2} \mathrm{PO}_{4}, 0.5 \mathrm{M} \mathrm{NaCl}(\mathrm{pH} 7.4$ ), and high-pressure homogenization was applied to lyse cells. After centrifugation at $12,000 \mathrm{rmp}$, the supernatant was loaded and purified Mpro was obtained by Ni-NTA affinity column with $0.02 \mathrm{M} \mathrm{Na}_{2} \mathrm{HPO}_{4} / \mathrm{NaH}_{2} \mathrm{PO}_{4}, 0.5 \mathrm{M} \mathrm{NaCl}, 500 \mathrm{mM}$ imidazole ( $\mathrm{pH}$ 7.4). The purified Mpro was stored in assay buffer $50 \mathrm{mM}$ Tris-HCl, 1 mM EDTA (pH 7.3) before use.

\subsection{LC-MS/MS analysis}

The LC-MS/MS analysis was performed by Shanghai Bioprofile Technology Co, Ltd. LC-MS/MS experiments were performed on a QEHFX mass spectrometer that was coupled to Easy nLC (Thermo Scientific). The sample was lysed by SDT (4\% SDS, $100 \mathrm{mM}$ DTT, $100 \mathrm{mM}$ TrisHCl) and redissolved in $200 \mu \mathrm{L}$ UA buffer ( $8 \mathrm{M}$ Urea, $150 \mathrm{mM}$ Tris$\mathrm{HCl}, \mathrm{pH} 8.0$ ). After digested for $16-18 \mathrm{~h}$ at $37^{\circ} \mathrm{C}$ by $40 \mu \mathrm{L}$ Trypsin buffer ( $6 \mu \mathrm{g}$ Trypsin in $40 \mu \mathrm{L} \mathrm{NH}_{4} \mathrm{HCO}_{3}$ buffer), the samples were centrifuged at $12,000 \mathrm{~g}$ for $10 \mathrm{~min}$. The filtrate contained peptide was collect and desalted by $\mathrm{C} 18$ StageTip. After vacuum drying, peptide was redissolved in $0.1 \%$ FA ( $0.1 \%$ Formic acid in water) and quantified at OD280 for LCMS/MS analysis. Peptide was first loaded to a trap column $(100 \mu \mathrm{m} * 20$ $\mathrm{mm}, 5 \mu \mathrm{m}, \mathrm{C} 18$, Dr. Maisch GmbH, Ammerbuch, Germany) in buffer A (0.1\% Formic acid in water). Reverse-phase high-performance liquid chromatography (RP-HPLC) separation was performed using a selfpacked column $(75 \mu \mathrm{m} \times 150 \mathrm{~mm}$; $3 \mu \mathrm{m}$ ReproSil-Pur C18 beads, 120 $\AA$, Dr. Maisch GmbH, Ammerbuch, Germany) at a flow rate of $300 \mathrm{~nL} /$ min. The RP-HPLC mobile phase A was $0.1 \%$ formic acid in water, and B was $0.1 \%$ formic acid in $95 \%$ acetonitrile. The gradient was set as following: 2-4\% buffer B from $0 \mathrm{~min}$ to $2 \mathrm{~min}, 4-30 \%$ buffer B from 2 min to $47 \mathrm{~min}, 30-45 \%$ buffer B from $47 \mathrm{~min}$ to $52 \mathrm{~min}, 45-90 \%$ buffer B from $52 \mathrm{~min}$ to $54 \mathrm{~min}, 90 \%$ buffer B kept till to $60 \mathrm{~min}$. MS data was acquired using a data-dependent top 20 method dynamically choosing 
the most abundant precursor ions from the survey scan (350-1800 $\mathrm{m} / \mathbf{z}$ ) for HCD fragmentation. A lock mass of 445.120025 Da was used as internal standard for mass calibration. The full MS scans were acquired at a resolution of 70,000 at $\mathrm{m} / \mathrm{z} 200$, and 17,500 at $\mathrm{m} / \mathrm{z} 200$ for MS/MS scan. The maximum injection time was set to for $50 \mathrm{~ms}$ for MS and $50 \mathrm{~ms}$ for MS/MS. Normalized collision energy was 27 and the isolation window was set to $1.6 \mathrm{Th}$. Dynamic exclusion duration was $60 \mathrm{~s}$.

\subsection{FRET assay for inhibition of Mpro [7]}

A buffer containing $50 \mathrm{mM}$ Tris-HCl and $1 \mathrm{mM}$ EDTA (pH 7.3) was used in inhibitory activity assay. The substrate with the cleavage site of SARS-CoV-2 Mpro MCA-AVLQSGFR-Lys(Dnp)-Lys-NH 2 (95\% purity, GL Biochem Shanghai Ltd, Shanghai, China) was employed in the fluorescence resonance energy transfer (FRET)-based cleavage assay. The fluorescent intensity was detected by a Flexstation 3 (Molecular Device) and the excitation and emission wavelength were $320 \mathrm{~nm}$ and $405 \mathrm{~nm}$, respectively. Firstly, for initially evaluate, stocked Mpro protein was diluted to the work concentration of $0.2 \mu \mathrm{M}$ in each well, $0.3 \mu \mathrm{M}$ tested compound and $20 \mu \mathrm{M}$ substrate were added and the reaction was stirred in a Tris- $\mathrm{HCl}$ buffer at $30{ }^{\circ} \mathrm{C}$. For the determination of the $\mathrm{IC}_{50}$, we used various concentrations $(0-10 \mu \mathrm{M})$ of tested compounds in reaction buffer at $30{ }^{\circ} \mathrm{C}$. It is reported that some compounds as aggregators can inhibit Mpro, thus $0.01 \%$ Triton X-100 was added into the reaction at the same time as detergent-based control. The $\mathrm{IC}_{50}$ value was determined by using the Origin 8.6 software. Each experiment was repeated at least five times.

\subsection{HPLC assay for inhibition of Mpro}

A buffer containing $50 \mathrm{mM}$ Tris- $\mathrm{HCl}$ and $1 \mathrm{mM}$ EDTA (pH 7.3) was used in the HPLC assay. As a blank control, the retention time and absorbance of Mpro substrate (SARS-CoV-2 Mpro MCA-AVLQSGFR-Lys (Dnp)-Lys- $\mathrm{NH}_{2}$ ) at $100 \mu \mathrm{M}$ was detected before further incubation with Mpro protein at $0.2 \mu \mathrm{M}$ for $30 \mathrm{~min}$ at $30^{\circ} \mathrm{C}$. For the measurement of inhibitory effect of ebselen or EBs at $0.3 \mu \mathrm{M}$ on Mpro, $0.2 \mu \mathrm{M}$ Mpro protein and $100 \mu \mathrm{M}$ substrate were added and stirred at $30^{\circ} \mathrm{C}$ for $30 \mathrm{~min}$ before the area under curve (AUC) of the substrate absorbance was detected using the HPLC assay. Column: Diamonsil C18, 4.6*250 mm, 5 $\mu \mathrm{m}$. Solvent A: $0.1 \%$ trifluoroacetic in $100 \%$ acetonitrile; solvent B: $0.1 \%$ trifluoroacetic in $100 \%$ water. $32 \% \mathrm{~A} / \mathrm{B}$ to $57 \% \mathrm{~A} / \mathrm{B}$ in $25 \mathrm{~min}$, at $1 \mathrm{~mL}$ $\min ^{-1}$ flow rate.

\subsection{Molecular modeling}

The crystal structure of ebselen to the SARS-CoV-2 Mpro complex (PDB: 7BFB) was obtained from the Protein Data Bank (http://www. rcsb.org/). Ligand, waters and ions were removed from PDB file.

The chemical structures of ebselen and ebselen derivatives were optimized in SYBYL (Tripos, St Louis, MO, USA) The chemical structures of ebselen and ebselen derivatives were sketched in SYBYL (Tripos, St Louis, MO, USA) and protonated, before energy minimization using the Tripos force field (Gasteiger-Hückel charges, distance-dependent dielectric constant $=4.0$, nonbonded interaction cutoff $=8 \AA$, and termination criterion $=$ energy gradient $<0.05 \mathrm{kcal} /(\mathrm{mol} \times \AA)$ for 10 000 iterations).

The molecular docking was performed on the program GOLD Suite 5.1 (Cambridge Crystallographic Data Center, Cambridge, U.K.). The original ligand was extracted and the new ligands were fit into the binding pocket of ebselen after defined Cys44 as binding site. The ChemScore was selected to fitness scoring function and the output results were also evaluated by the GoldScore function. The exported complexes were edited by UCSF Chimera 1.15 software.

\subsection{Cytotoxicity test}

Each well was cultivated with different concentrations of ebselen derivatives for $24 \mathrm{~h}$, and then treated with $10 \mu \mathrm{L}$ of MTT solution for $4 \mathrm{~h}$. After discarding the medium contained MTT of each well, DMSO was added. OD values (Optical density) of each well were measured with a Microplate Reader at $490 \mathrm{~nm}$. The $\mathrm{CC}_{50}$ values were calculated with dose-response curves by GraphPad Prism 5. Each well was duplicated for five times.

For measurement of ROS-induced cell death, HPAepiC cells were exposed to $50 \mu \mathrm{M} \mathrm{H}_{2} \mathrm{O}_{2}$ for $1 \mathrm{~h}$ before washed with fresh medium for three times. Cells were treated with medium contained $10 \mathrm{mM}$ NAC $(\mathrm{N}$ acetyl-L-cysteine), $10 \mu \mathrm{M}$ ebselen, EB2-7, EB2-9 or EB2-19 for $24 \mathrm{~h}$.

\subsection{Antiviral assays}

The antiviral activity of ebselen derivative was determined using reported method [4]. HPAepiC cells were infected with SARS-CoV-2 at MOI of 0.1 with or without drug candidates for $1 \mathrm{~h}$. The equivalent amount of DMSO was used as solvent control. Virus-drug mixture was removed before cells were further cultured with fresh drug-free RPMI 1640 medium with $3 \%$ FBS. $24 \mathrm{~h}$ post infection, total RNAs of cells were extracted. For detection of SARS-CoV-2 RNA, a THUNDERBIRD Probe One-Step qRT-PCR Kit (QRZ-101, TOYOBO, Japan) was used in accordance with the manufacturer's protocols. Primers and probes used in this experiment included forward primer $5^{\prime}$-GGGGAACTTCTCCTGCTAGAAT- $3^{\prime}$, reverse primer $5^{\prime}$-CAGACATTTTGCTCTCAAGCTG-3', and probe FAM-TTGCTGCTGCTTGACAGATT-TAMRA-3' [35]. In each run, serial dilutions of the SARS-CoV-2 RNA reference standard (GBW(E) 091089, National Institute of Metrology, China) were carried out in parallel to determine the viral RNA copies per $\mu \mathrm{g}$ RNA. $\mathrm{IC}_{50}$ values were calculated using the GraphPad Prism 6 software using reported methods (Version 6.01, GraphPad Software, Inc., San Diego, CA, 2012) [36-38]. All experiments were performed at biosafety level-3 (BSL-3) in the Kunming National High-Level Biosafety Research Center for NonHuman Primates, Center for Biosafety Mega-Science, Kunming Institute of Zoology, Chinese Academy of Sciences.

\subsection{Measurement of intracellular reactive oxygen (ROS)}

The generation of intracellular reactive oxygen was measured by an oxidation-sensitive probe $2^{\prime}, 7^{\prime}$-dichlorodihydrofluoresceindiacetate (DCFH-DA, Beyotime Institute of Biotechnology, China). DCFH-DA can be cleaved by esterases, and then becomes highly fluorescent DCFH upon oxidation by ROS. HPAepiC cells were seed in 35-mm dishes and cultured in prepared medium for $24 \mathrm{~h}$. Then, HPAepiC cells were exposed to $50 \mu \mathrm{M} \mathrm{H}_{2} \mathrm{O}_{2}$ for $1 \mathrm{~h}$, and washed with fresh medium for three times. Cells were treated with medium contained $10 \mu \mathrm{M}$ ebselen, EB2-7, EB2-9, EB2-19 for $24 \mathrm{~h}$. Cells treated with $10 \mathrm{mM}$ NAC ( $N$-acetyl-Lcysteine) were used as positive control for inhibition of ROS generation. Then cells were incubated with $10 \mu \mathrm{M}$ DCFH-DA at $37{ }^{\circ} \mathrm{C}$ for $30 \mathrm{~min}$ in the dark before washed with PBS for three times. The cell imaging of DCFH was captured by confocal fluorescence microscopy. Ex: $488 \mathrm{~nm}$ Em: $520-570 \mathrm{~nm}$.

\subsection{Statistical analysis}

The $\mathrm{IC}_{50}$ values of Mpro inhibitors were calculated using the Origin 8.6 software. The $\mathrm{IC}_{50}$ values of antiviral drugs were calculated using the GraphPad Prism 6 software (Version 6.01, GraphPad Software, Inc., San Diego, CA, 2012).

\section{Declaration of Competing Interest}

The authors declare that they have no known competing financial interests or personal relationships that could have appeared to influence 
the work reported in this paper.

\section{Acknowledgments}

We thank Dr. Peng Wang (Dalian Institute of Chemical Physics, Chinese Academy of Science) for the HPAepiC cells. We thank Dr. Rilei $\mathrm{Yu}$ (Key Laboratory of Marine Drugs, Chinese Ministry of Education, School of Medicine and Pharmacy, Ocean University of China) for the molecular docking software. We also thank Shanghai Bioprofile Technology Company Ltd. for technical support in mass spectroscopy. This project was supported by grants awarded to K.W.W. from the Science and Technology Program of Guangdong, China (2018B030334001).

\section{Appendix A. Supplementary material}

Supplementary data to this article can be found online at https://doi. org/10.1016/j.bioorg.2021.105455.

\section{References}

[1] F. Wu, S.u. Zhao, B. Yu, Y.-M. Chen, W. Wang, Z.-G. Song, Y.i. Hu, Z.-W. Tao, J.H. Tian, Y.-Y. Pei, M.-L. Yuan, Y.-L. Zhang, F.-H. Dai, Y.i. Liu, Q.-M. Wang, J.J. Zheng, L. Xu, E.C. Holmes, Y.-Z. Zhang, A new coronavirus associated with human respiratory disease in China, Nature 579 (7798) (2020) 265-269.

[2] P. Zhou, X.-L. Yang, X.-G. Wang, B. Hu, L. Zhang, W. Zhang, H.-R. Si, Y. Zhu, B. Li, C.-L. Huang, H.-D. Chen, J. Chen, Y. Luo, H. Guo, R.-D. Jiang, M.-Q. Liu, Y. Chen, X.-R. Shen, X.i. Wang, X.-S. Zheng, K. Zhao, Q.-J. Chen, F. Deng, L.-L. Liu, B. Yan, F.-X. Zhan, Y.-Y. Wang, G.-F. Xiao, Z.-L. Shi, A pneumonia outbreak associated with a new coronavirus of probable bat origin, Nature 579 (7798) (2020) 270-273.

[3] K. Anand, J. Ziebuhr, P. Wadhwani, J.R. Mesters, R. Hilgenfeld, Coronavirus main proteinase (3CLpro) structure: basis for design of anti-SARS drugs, Science 300 (5626) (2003) 1763-1767.

[4] L. Zhang, D. Lin, X. Sun, U. Curth, C. Drosten, L. Sauerhering, S. Becker, K. Rox, R. Hilgenfeld, Crystal structure of SARS-CoV-2 main protease provides a basis for design of improved alpha-ketoamide inhibitors, Science 368 (6489) (2020) 409-412.

[5] R. Hilgenfeld, From SARS to MERS: crystallographic studies on coronaviral proteases enable antiviral drug design, FEBS J.. 281 (18) (2014) 4085-4096.

[6] L. Zhang, D. Lin, Y. Kusov, Y. Nian, Q. Ma, J. Wang, A. von Brunn, P. Leyssen, K. Lanko, J. Neyts, A. de Wilde, E.J. Snijder, H. Liu, R. Hilgenfeld, alphaKetoamides as broad-spectrum inhibitors of coronavirus and enterovirus replication: structure-based design, synthesis, and activity assessment, J. Med. Chem. 63 (9) (2020) 4562-4578.

[7] H. Yang, W. Xie, X. Xue, K. Yang, J. Ma, W. Liang, Q.i. Zhao, Z. Zhou, D. Pei, J. Ziebuhr, R. Hilgenfeld, K.Y. Yuen, L. Wong, G. Gao, S. Chen, Z. Chen, D. Ma, M. Bartlam, Z. Rao, P. Bjorkman, Design of wide-spectrum inhibitors targeting coronavirus main proteases, PLoS Biol. 3 (10) (2005) e324, https://doi.org/ 10.1371/journal.pbio.003032410.1371/journal.pbio.0030324.g00110.1371/ journal.pbio.0030324.g00210.1371/journal.pbio.0030324.g00310.1371/journal. pbio.0030324.g00410.1371/journal.pbio.0030324.t00110.1371/journal. pbio.0030324.sg00110.1371/journal.pbio.0030324.sg00210.1371/journal. pbio.0030324.sg00310.1371/journal.pbio.0030324.st00110.1371/journal. pbio.0030324.st00210.1371/journal.pbio.0030324.st00310.1371/journal. pbio.0030324.sd001.

[8] T. Pillaiyar, M. Manickam, V. Namasivayam, Y. Hayashi, S.H. Jung, An overview of severe acute respiratory syndrome-coronavirus (SARS-CoV) 3CL protease inhibitors: peptidomimetics and small molecule chemotherapy, J. Med. Chem. 59 (14) (2016) 6595-6628.

[9] W. Zhu, M. Xu, C.Z. Chen, H. Guo, M. Shen, X. Hu, P. Shinn, C. Klumpp-Thomas, S. G. Michael, W. Zheng, Identification of SARS-CoV-2 3CL protease inhibitors by a quantitative high-throughput screening, ACS Pharmacol. Transl. Sci. 3 (5) (2020) 1008-1016.

[10] L.Y. Sun, C. Chen, J. Su, J.Q. Li, Z. Jiang, H. Gao, J.Z. Chigan, H.H. Ding, L. Zhai, K. W. Yang, Ebsulfur and Ebselen as highly potent scaffolds for the development of potential SARS-CoV-2 antivirals, Bioorg. Chem. 112 (2021), 104889.

[11] J. Loschwitz, A. Jackering, M. Keutmann, M. Olagunju, R.J. Eberle, M.A. Coronado, O.O. Olubiyi, B. Strodel, Novel inhibitors of the main protease enzyme of SARSCoV-2 identified via molecular dynamics simulation-guided in vitro assay, Bioorg. Chem. 111 (2021), 104862.

[12] S. Guo, H. Xie, Y. Lei, B. Liu, L. Zhang, Y. Xu, Z. Zuo, Discovery of novel inhibitors against main protease (Mpro) of SARS-CoV-2 via virtual screening and biochemical evaluation, Bioorg. Chem. 110 (2021), 104767.

[13] A.S. Girgis, S.S. Panda, A.M. Srour, A. Abdelnaser, S. Nasr, Y. Moatasim, O. Kutkat, A. El Taweel, A. Kandeil, A. Mostafa, M.A. Ali, N.G. Fawzy, M.S. Bekheit, E. M. Shalaby, L. Gigli, W. Fayad, A.A.F. Soliman, 3-Alkenyl-2-oxindoles: Synthesis, antiproliferative and antiviral properties against SARS-CoV-2, Bioorg. Chem. 114 (2021), 105131.

[14] Z. Jin, X. Du, Y. Xu, Y. Deng, M. Liu, Y. Zhao, B. Zhang, X. Li, L. Zhang, C. Peng, Y. Duan, J. Yu, L. Wang, K. Yang, F. Liu, R. Jiang, X. Yang, T. You, X. Liu, X. Yang,
F. Bai, H. Liu, X. Liu, L.W. Guddat, W. Xu, G. Xiao, C. Qin, Z. Shi, H. Jiang, Z. Rao, H. Yang, Structure of M(pro) from SARS-CoV-2 and discovery of its inhibitors, Nature 582 (7811) (2020) 289-293.

[15] C.V. Haritha, K. Sharun, B. Jose, Ebselen, a new candidate therapeutic against SARS-CoV-2, Int. J. Surg. 84 (2020) 53-56.

[16] H. Sies, M.J. Parnham, Potential therapeutic use of ebselen for COVID-19 and other respiratory viral infections, Free Radical. Bio. Med. 156 (2020) 107-112.

[17] T. Schewe, Molecular actions of ebselen - an antiinflammatory antioxidant, Gen Pharmacol.-Vasc. S 26 (6) (1995) 1153-1169.

[18] A. Batna, C. Fuchs, G. Spiteller, Lipid peroxidation in presence of ebselen, Chem. Phys. Lipids 87 (2) (1997) 149-158.

[19] P. Chew, D.Y.C. Yuen, N. Stefanovic, J. Pete, M.T. Coughlan, K.A. Jandeleit-Dahm, M.C. Thomas, F. Rosenfeldt, M.E. Cooper, J.B.d. Haan, Antiatherosclerotic and renoprotective effects of ebselen in the diabetic apolipoprotein E/GPx1-double knockout mouse, Diabetes 59 (12) (2010) 3198-3207.

[20] P. Chew, D.Y.C. Yuen, P. Koh, N. Stefanovic, M.A. Febbraio, I. Kola, M.E. Cooper, J. B. de Haan, Site-specific antiatherogenic effect of the antioxidant ebselen in the diabetic apolipoprotein E-deficient mouse, Arterioscl. Throm. Vas. 29 (6) (2009) 823-830.

[21] N. Singh, A.C. Halliday, J.M. Thomas, O.V. Kuznetsova, R. Baldwin, E.C.Y. Woon, P.K. Aley, I. Antoniadou, T. Sharp, S.R. Vasudevan, G.C. Churchill, A safe lithium mimetic for bipolar disorder, Nat. Commun. 4 (1) (2013), https://doi.org/ $10.1038 /$ ncomms 2320.

[22] A. Wendel, M. Fausel, H. Safayhi, G. Tiegs, R. Otter, A novel biologically-active organoselenium compound. 2. Activity of Pz-51 in relation to glutathioneperoxidase, Biochem. Pharmacol. 33 (20) (1984) 3241-3245.

[23] H. Safayhi, G. Tiegs, A. Wendel, A Novel Biologically-active seleno-organic compound. 5. inhibition by ebselen (Pz-51) of rat peritoneal neutrophil lipoxygenase, Biochem. Pharmacol. 34 (15) (1985) 2691-2694.

[24] K. Bijian, Z. Zhang, B. Xu, S.u. Jie, B.o. Chen, S. Wan, JianHui Wu, T. Jiang, M. A. Alaoui-Jamali, Synthesis and biological activity of novel organoselenium derivatives targeting multiple kinases and capable of inhibiting cancer progression to metastases, Eur. J. Med. Chem. 48 (2012) 143-152.

[25] A.L. Sharpley, C. Williams, A.A. Holder, B.R. Godlewska, N. Singh, M. Shanyinde, O. MacDonald, P.J. Cowen, A phase 2a randomised, double-blind, placebocontrolled, parallel-group, add-on clinical trial of ebselen (SPI-1005) as a novel treatment for mania or hypomania, Psychopharmacology 237 (12) (2020) 3773-3782.

[26] A.C. Ruberte, C. Sanmartin, C. Aydillo, A.K. Sharma, D. Plano, Development and therapeutic potential of selenazo compounds, J. Med. Chem. 63 (4) (2020) 1473-1489.

[27] C. Ma, Y. Hu, J.A. Townsend, P.I. Lagarias, M.T. Marty, A. Kolocouris, J. Wang, Ebselen, disulfiram, carmofur, PX-12, tideglusib, and shikonin are nonspecific promiscuous SARS-CoV-2 main protease inhibitors, ACS Pharmacol. Transl. Sci. 3 (6) (2020) 1265-1277.

[28] K. Amporndanai, X. Meng, W. Shang, Z. Jin, M. Rogers, Y. Zhao, Z. Rao, Z.J. Liu, H. Yang, L. Zhang, P.M. O'Neill, S. Samar Hasnain, Inhibition mechanism of SARSCoV-2 main protease by ebselen and its derivatives, Nat. Commun. 12 (1) (2021) 3061.

[29] Cintia A. Menéndez, Fabian Byléhn, Gustavo R. Perez-Lemus, Walter Alvarado, Juan J. de Pablo, Molecular characterization of ebselen binding activity to SARSCoV-2 main protease, Sci. Adv. 6 (37) (2020), https://doi.org/10.1126/sciadv. abd0345.

[30] A. Aljoundi, I. Bjij, A. El Rashedy, M.E.S. Soliman, Covalent versus non-covalent enzyme inhibition: which route should we take? A justification of the good and bad from molecular modelling perspective, Protein J. 39 (2) (2020) 97-105.

[31] Stephane De Cesco, Jerry Kurian, Caroline Dufresne, Anthony K. Mittermaier, Nicolas Moitessier, Covalent inhibitors design and discovery, Eur. J. Med. Chem. 138 (2017) 96-114.

[32] Brian Y Feng, Brian K Shoichet, A detergent-based assay for the detection of promiscuous inhibitors, Nat. Protoc. 1 (2) (2006) 550-553.

[33] Sonia Antony, Craig A. Bayse, Modeling the mechanism of the glutathione peroxidase mimic ebselen, Inorg. Chem. 50 (23) (2011) 12075-12084.

[34] S. Thanna, C.M. Goins, S.E. Knudson, R.A. Slayden, D.R. Ronning, S.J. Sucheck, Thermal and photoinduced copper-promoted C-Se bond formation: synthesis of 2 Alkyl-1,2-benzisoselenazol-3(2H)-ones and evaluation against mycobacterium tuberculosis, J. Org. Chem. 82 (7) (2017) 3844-3854.

[35] T.Z. Song, H.Y. Zheng, J.B. Han, L. Jin, X. Yang, F.L. Liu, R.H. Luo, R.R. Tian, H. R. Cai, X.L. Feng, C. Liu, M.H. Li, Y.T. Zheng, Delayed severe cytokine storm and immune cell infiltration in SARS-CoV-2-infected aged Chinese rhesus macaques, Zool. Res. 41 (5) (2020) 503-516.

[36] L.Y. Wang, F.Z. Bu, Y.M. Yu, Y.Y. Niu, Y.T. Li, C.W. Yan, Z.Y. Wu, A novel crystalline molecular salt of sulfamethoxazole and amantadine hybridizing antiviral-antibacterial dual drugs with optimal in vitro/vivo pharmaceutical properties, Eur. J. Pharm. Sci. 163 (2021), 105883.

[37] Ling-Yang Wang, Yuan-Yuan Niu, Ming-Yu Zhao, Yue-Ming Yu, Yan-Tuan Li, ZhiYong Wu, Cui-Wei Yan, Supramolecular self-assembly of amantadine hydrochloride with ferulic acid via dual optimization strategy establishes a precedent of synergistic antiviral drug-phenolic acid nutraceutical cocrystal, Analyst 146 (12) (2021) 3988-3999.

[38] L.Y. Wang, M.Y. Zhao, F.Z. Bu, Y.Y. Niu, Y.M. Yu, Y.T. Li, C.W. Yan, Z.Y. Wu, Cocrystallization of amantadine hydrochloride with resveratrol: the first drugnutraceutical cocrystal displaying synergistic antiviral activity, Cryst. Growth Des. 21 (5) (2021) 2763-2776. 